\title{
ENVIRONMENTAL ASPECTS AND FEATURES OF CRITICAL PATHOGEN GROUPS
}

\section{Tiong Aw}

Tulane University

New Orleans, United States 


\section{Copyright:}

\section{cc) (1) (2) \\ BY SA}

This publication is available in Open Access under the Attribution-ShareAlike 3.0 IGO (CC-BY-SA 3.0 IGO) license (http://creativecommons.org/licenses/by-sa/3.0/igo). By using the content of this publication, the users accept to be bound by the terms of use of the UNESCO Open Access Repository (http://www.unesco.org/open-access/terms-use-ccbysa-en).

\section{Disclaimer:}

The designations employed and the presentation of material throughout this publication do not imply the expression of any opinion whatsoever on the part of UNESCO concerning the legal status of any country, territory, city or area or of its authorities, or concerning the delimitation of its frontiers or boundaries. The ideas and opinions expressed in this publication are those of the authors; they are not necessarily those of UNESCO and do not commit the Organization.

\section{Citation:}

Aw, T. 2018. Environmental Aspects and Features of Critical Pathogen Groups. In: J.B. Rose and B. JiménezCisneros, (eds) Water and Sanitation for the 21st Century: Health and Microbiological Aspects of Excreta and Wastewater Management (Global Water Pathogen Project). (J.B. Rose and B. Jiménez-

Cisneros (eds) Part 1: The Health Hazards of Excreta: Theory and Control), Michigan State University, E. Lansing, MI, UNESCO. https://doi.org/10.14321/waterpathogens.2

Acknowledgements: K.R.L. Young, Project Design editor; Website Design: Agroknow (https://www.agroknow.com)

Last published: July 4, 2018 


\section{Summary}

This chapter provides the reader with an overview of various environmental aspects and characteristics of critical pathogen groups (disease-causing microorganisms) associated with fecal wastes, sewage and water-related diseases including viruses, bacteria, protists and helminths. The sources of these pathogens are primarily human feces but the reservoirs can be humans, animals or the environment itself. The handling and methods of human or animal waste disposal play a significant role in transmission of infectious diseases globally. The diseases caused by water-related pathogens range from mild gastroenteritis to severe diarrhea, dysentery, typhoid fever and hepatitis. Some water-related infections have chronic sequelae. The risks of infection are dependent on specific characteristics of the pathogen including potency/infectiousness, concentrations in excreta, their ability to persist in the environment and resistance to sewage treatment. Pathogen concentrations particularly viruses and bacteria in excreta and sewage is high, typically at concentrations of millions to billions of organisms. For pathogens transmitted via fecal-oral route, persistence in the environment is related to risk of host exposure and potentially disease. Viruses, protozoan cysts and oocysts and helminths persist longer in the environment than vegetative bacteria. In contrast to other pathogen groups, all helminths have a distinct latency period in the environment and some require intermediate hosts to complete their life cycles. In general, viruses, protists and helminths pose higher risks of infection (highly potent) than bacteria and resulting disease from ingestion of or contact with very low doses of the pathogen. In addition, the risks of infection by water-related pathogens are influenced by other environmental factors including their potential sources or reservoirs in the environment such as animal (zoonosis) fecal contamination, and their ability to be transported (e.g. vectors) in the environment to reach susceptible hosts. Majority of the bacteria, protists and helminths are zoonotic pathogens. Vectors such as freshwater snails and rodents play an important role in transmission of infectious diseases caused by some protists (e.g. Leptospirosis) and most of the helminths. Overall, water-related pathogens are one of the major contributors to the global burden of disease. Understanding how pathogens survive and move in the environment, their sources and transmission routes are crucial to developing effective interventions to reduce water-related diseases.

\subsection{Overview: Environmentally Transmitted Pathogens}

Microorganisms are ubiquitous in the environment and humans are continually exposed to a vast array of microorganisms. However, only a small proportion of microorganisms are capable of interacting with the host and causing disease (NIH, 2007). Microorganisms that are capable of causing disease are called pathogens and enteric pathogens in particular are gastrointestinal microorganisms transmitted by the fecal-oral route (Figure $1)$.

Table 1 summarizes the terminology and definitions used to describe fecal-oral and water-related pathogens. An infectious disease is a disease that is caused by the invasion of a susceptible host by pathogens whose activities harm the host's tissues and can be transmitted to other individuals. This process often involves proliferation of pathogens in a host and excretion of these pathogens by the infected host in their feces. The fecal excretion by infected hosts plays an important role in disease transmission due to the potential of introducing pathogens into the environment that later may be ingested again by other susceptible humans or animals and multiply in the newly infected host referred to as fecal-oral (Carr, 2001). Environmental factors, particularly the water environment and the method of human or animal waste disposal, are critical to the likely transmission of infectious diseases caused by these enteric pathogens globally (Prüss-Ustün et al., 2014). Most fecal pathogens are immediately infectious/contagious upon excretion and end up in water. Enteric pathogens are characteristically stable in water environments and waterborne transmission is a highly effective means for spreading pathogens to a large portion of the population. 
Table 1. Terminology and concepts important to waterborne disease

\section{Terminology/ Concept}

Intermediate host

Opportunistic

infections

Pathogen

Waterborne

diseases

Water-washed diseases

Water-based diseases

Water-related insect vector diseases

\section{Definition}

\section{Examples}

Enteric pathogens discussed in

The pathogens that cause diseases are found in the feces of an infected person or animal. These pathogens are shed by an infected person or animal and then are transmitted to the next susceptible person's mouth to cause infection.

Important for helminth life cycles where the host at which a parasite spends its final development stage and reaches its mature form and reproduces sexually (producing an ova or egg).

Important for helminth life cycles where the host that harbors a parasite allows the parasite to grow, but where no sexual reproduction occurs. The intermediate host often acts as vector of parasite to reach its definitive host (where it will become mature).

Important for helminths and a few protozoa. Time for the egg (ova or oocyst) to become mature and infectious in the environment after excretion.

Infections that occur more frequently and are more severe in individuals with weakened immune systems such as immunocompromised patients with AIDS.

Disease-causing microorganisms.

Infections caused by pathogens that originate in feces and are transmitted predominantly through the ingestion of fecal contaminated water. This class of diseases is closely related to water quality and safety. Control of waterborne diseases is generally through water treatment and source protection to improve microbial water quality.

Infections caused by pathogens that are transmitted through contact due to poor sanitation and hygiene resulting from inadequate water availability. In contrast to waterborne diseases, the role of water for the water-washed diseases is in prevention of disease transmission rather than as a vehicle for transmitting pathogens. Control of water-washed diseases is through providing accessible to water and education to improve personal and domestic hygiene.

Infections caused by pathogens that originate in the water or spend part of their life cycle in the water and another part as parasites of aquatic animals as intermediate hosts. Water-based diseases can be controlled through protection of water source, limiting skin contact with contaminated water and eradication of intermediate hosts.

Infections caused by pathogens with life cycles associated with insect vectors, e.g. mosquitoes that live or breed in or near stagnant water. Several strategies to control this category of diseases include destruction of vector breeding grounds, the use of pesticides and construction of drainage system to reduce human exposure to insects.

Infectious diseases that are spread between animals and humans. this chapter can be transmitted by the fecal-oral route. Enteric pathogens are spread by fecally contaminated hands, food and water.

Helminths such as the Cestodes (tapeworms) make use of humans as the definitive host.

Fresh water snails associated with shistosomiasis.

Helminths, Cyclospora and Toxocara

Not infectious in feces upon excretion.

Microsporidiosis is an opportunistic disease that is caused by small parasites, Microsporidia.

Norovirus, rotavirus, Shigella, Salmonella, Cryptosporidium, Giardia, Schistosoma

Cholera, typhoid fever, dysentery are the iconic diseases, all fecaloral pathogens can be waterborne.

Trachoma, conjunctivitis, scabies

Dracunculiasis (caused by the guinea worm Dracunculus medinensis), shistosomiasis (snail fever)

Yellow fever, dengue, malaria, filariasis, onchocerciasis, sleeping sickness.

Important zoonotic pathogens are found in the bacteria (Salmonella, Campylobacter, ) protozoa (Cryptosporidium parvum, Giardia lamblia) and helminths (Taenia solium) 


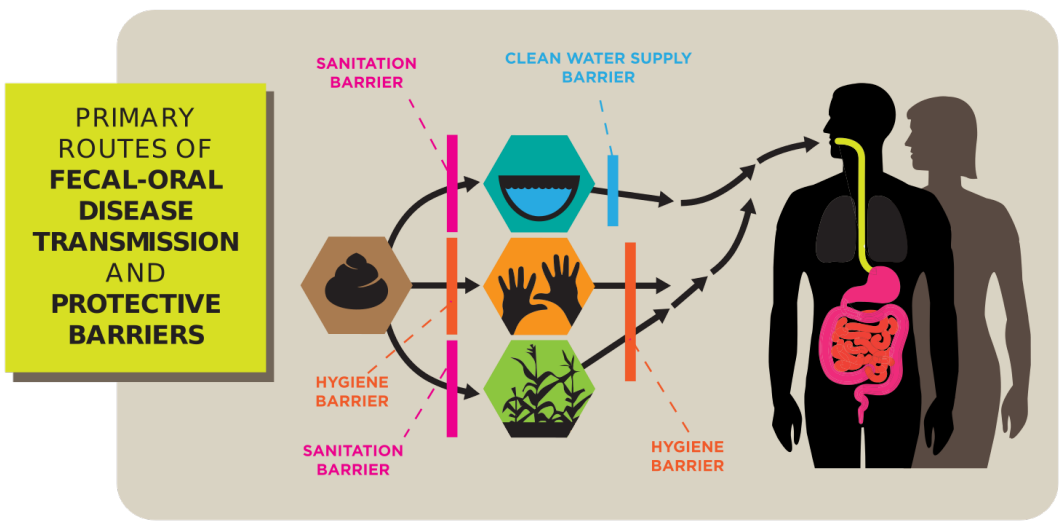

Most fecal-oral pathogens are immediately infectious and are spread through hands, water, and food contaminated with feces which are swallowed by the next susceptible individual. Sanitation, hygiene and drinking water treatment are all barriers to transmission.

This exposure pathway includes most viruses, bacteria and protozoa. With many bacteria and protozoa, infected animals and their feces can also spread the diseases caused by these pathogens.

Figure 1. Primary routes of fecal-oral disease transmission and protective. (Created by Design2 for the GWPP)

Historical research on many diseases clearly demonstrated that the evolution of humans and pathogens is interconnected: human migration and global trade have disseminated infectious disease, e.g. cholera; global environmental change has expanded the range of known pathogens or created the conditions for other microorganisms to emerge as significant pathogens; traditional and modern methods of livestock farming create a risk from emerging zoonotic diseases (WHO, 2003). Developments in our understanding of the relationships between water and human health have been fueled by the periodic identification of water-related pathogens including previously unknown pathogens (Ramees et al., 2017; Gibson, 2014). Infectious, particularly water-related diseases are still a major cause of morbidity and mortality worldwide (Wolf et al. 2014). Since 1970, several species of microorganisms from human and animal fecal material and from environmental sources, e.g. water have been recognized as pathogens such as Escherichia coli 0157, rotaviruses, noroviruses, Cryptosporidium and Giardia (WHO, 2003). The importance of water in the transmission of these excreted-related pathogens and other new pathogens is being continually assessed as new technologies for diagnostics become available (Aw and Rose, 2012; Tan et al., 2015).

\subsection{Excreta-related and Water-related Infections and Their Classifications}

A large number of infectious diseases are related to excreta (feces and urine), from both human and animals and key three features promote environmental transmission.

- Excreted in high numbers in feces

- Persistent in the environment

- Highly infectious
Excreta generally contain high concentrations of pathogens, particularly in regions where diarrheal diseases and intestinal parasites are prevalent. Therefore, human and animal excreta are the largest source of environmental loading of pathogens associated with waterborne disease transmission. Some of these pathogens can remain infectious for long periods of time after being introduced to the environment, and under certain conditions, they are capable of replicating in the environment.

Excreta-related infections are transmitted through a variety of routes from one host to the next, either as a result of direct transmission through fecally-contaminated hands, or indirect transmission via fecally-contaminated water, soil, food and fomites such as surfaces and household utensils (Brown et al., 2013). Water has been identified as the most important environmental factor in the transmission of excreta-related infections. While feces are the source, it is the land use and infrastructure that influences the transport via climate factors particularly rainfall. A recent systematic review of studies on water quality indicated that fecal contamination of drinking water in low- and middle-income countries is widespread (Bain et al., 2014) and there was a significant seasonal trend of the fecal contamination in improved drinking water sources with greater contamination during the wet season (Kostyla et al., 2015).

It has long been recognized that an environmental classification of excreta-related and water-related infections according to their transmission routes, is needed to guide environmental and medical practitioners as well as engineers in developing and implementing interventions to interrupt these routes thus leading to reduction in the burden of infection and disease. David Bradley and his coworkers developed the first environmental classification of water related-infections in 1972 (White et al., 1972). The 
classification, known as the "Bradley Classification" comprised of four broad classes of water-related infections: waterborne, water washed, water based and water related insect vector. This method of classification based on their route of transmission, not traditional epidemiology, provides a useful framework for understanding the relationship between infectious disease transmission and water (definitions found in Table 1).

Waterborne diseases are infections caused by fecal-oral pathogens, which are transmitted predominantly through the ingestion of fecal contaminated water. This class of diseases is closely related to water quality and safety. The transmission by this route mainly depends on (i) the amount of fecal contamination, particularly pathogen load released into the environment; (ii) the growth and/or persistence of the pathogen; and (iii) the infectivity (infectious dose as a dose-response) related to the individual exposure through ingestion of the contaminated water. The exposure paths include drinking water, recreational water, irrigation water and waters used for hygiene. The classic waterborne diseases such as typhoid (caused by Salmonella typhi), cholera (caused by toxigenic strains of Vibrio cholerae) and dysentery (caused by Shigella spp. and Entamoeba histolytica) have been controlled in mostly developed countries by the protection of water sources and by water and wastewater treatment. However, these classic waterborne diseases continue to be a problem in the developing regions. Control of waterborne diseases is generally through water treatment and source protection from fecal contamination which improves microbial water quality.

Water-washed diseases are infections closely associated with poor sanitation and hygiene resulting from inadequate water availability. These diseases are not caused by the poor water quality but rather by the lack of water availability for washing of contaminated hands and utensils to prevent the transmission of pathogens such as Shigella spp. (see Part Three, Section II). In contrast to waterborne diseases, the role of water for the water-washed diseases is in prevention of disease transmission rather than as a vehicle for transmitting pathogens. Fecal-oral associated water-washed diseases such as diarrhea may be transmitted through person-to-person contact or indirect contact with contaminated food and utensils. The lack of water, particularly in developing countries for washing and bathing contributes to diseases affecting the eye and skin such as trachoma, conjunctivitis and scabies. Control of water-washed diseases is through access to water and education to improve personal and domestic hygiene.

Water-based diseases are infections caused by pathogens that originate in the water or spend part of their life cycle in the water and another part as parasite of aquatic animals as intermediate hosts. This group of diseases can be further divided into diseases acquired by water ingestion such as dracunculiasis (caused by the guinea worm Dracunculus medinensis) and diseases acquired by water contact such as schistosomiasis (caused by parasitic helminth Schistosoma spp., see Part Three, Section IV). Water-based diseases can be controlled through protection of water source, limiting skin contact with contaminated water and eradication of intermediate hosts.

Water-related insect vector diseases are infections caused by pathogens with life cycles associated with vectors such as insects, e.g. mosquitoes that live or breed in or near stagnant water. Examples of water-related diseases are yellow fever, dengue, malaria, filariasis, onchocerciasis and sleeping sickness. Several strategies to control this category of diseases include destruction of vector breeding grounds, the use of pesticides and construction of drainage system to reduce human exposure to insects.

\subsection{Overview of Groups of Fecal-associated Pathogens}

The human health effects caused by these watertransmitted pathogens vary in severity from mild gastroenteritis to severe diarrhea, dysentery, typhoid fever and hepatitis. Some water-related infections have chronic sequelae, e.g. myocarditis associated with coxsackieviruses, hemolytic-uremic syndrome (HUS) associated with pathogenic E. coli 0157:H7, stomach cancer associated with Helicobacter pylori, and reactive pericarditis associated with Shigella, Yersinia and Salmonella (Leclerc et al., 2002).

These represent a number of taxonomically different microorganisms which are important water-transmitted pathogens. Improved methods of surveillance, epidemiological studies and the development of advanced methods of pathogen detection (mainly molecular methods such as polymerase chain reaction) have allowed the discovery of new pathogens associated with water-related diseases. However, it is important to recognize that the majority of microorganisms in the environment and the human intestine have not been cultured or characterized (Kroes et al.,1999). Therefore, this poses a potential public health risk of the emergence of an as yet unrecognized agent of infectious disease. There are four major groups of pathogens that cause the majority of waterborne disease which range in size from smallest to largest and include viruses, bacteria, protists and helminthes (see Part Three, Section I to IV). A brief review of the general characteristics of each of these pathogen groups and examples of some diseases they cause is discussed below.

\subsection{Viruses}

Viruses are infectious agents that are obligatory intracellular parasites, which means they must be inside a host cell to reproduce. Viruses are not organisms themselves because, outside a host cell, viruses have no metabolism, do not carry out respiratory or biosynthetic functions and cannot reproduce. Nevertheless, viruses possess a degree of robustness, which allows them to remain infectious (able to infect the next individual) outside of the susceptible host. This is well documented by the increasing number of outbreaks of waterborne disease cause by enteric viruses worldwide (Ligon and Bartram, 2016). 
Viruses are very small only seen under the electron microscope and range from about 0.02 to $0.1 \mu \mathrm{m}$. A virus particle, known as a virion, consists of nucleic acid that is surrounded by a protective protein coat called a capsid. Viral nucleic acids can consist of single- or double- stranded deoxyribonucleic acid (DNA) or ribonucleic acid (RNA) but not both. Viruses are genetically diverse and capable of adapting to the changing conditions of the host cells and the environment (Hulo et al., 2010), for example, there are currently 39 genotypes of norovirus (Vinjé, 2015).

Each virus transmitted via water has a specific repertoire of host cells (e.g. intestinal tract and liver), which it can invade to initiate an infection. In addition, the viruses show strong host species specificity. The majority of waterborne viral infections are caused by enteric viruses, which are non-enveloped viruses such as enteroviruses (poliovirus, coxsackievirus, echovirus), noroviruses (formerly known as the Norwalk-like viruses), adenoviruses, rotaviruses, astrovirus, hepatitis A and E viruses. Besides classic enteric viruses, recent studies have focused on the identification of emerging or newly identified viruses, e.g. polyomavirus, papillomavirus, Aichi viruses, saliviruses (Itta et al., 2016; Reuter et al., 2016) associated with water and wastewater. Enteric viruses are associated with a variety of diseases such as gastroenteritis, hepatitis, myocarditis, and meningitis in humans (Table 2). In developed countries, noroviruses are identified as the most common cause of acute non-bacterial gastroenteritis in both children and adults (Ahmed et al., 2014). In developing countries, rotaviruses play a larger role as they are the leading cause of acute gastroenteritis in infants and young children across southern Asia and sub-Saharan Africa (see Part Three, Section I. Rotavirus and Astrovirus).

Table 2. Viruses and examples of acute and chronic diseases they cause

\begin{tabular}{cccc}
\hline Pathogen & Acute Disease(s) & Chronic Disease(s) & Reference \\
\hline Viruses (small nano-sized simple structured organism, & $\mathbf{0 . 0 2}$ to $0.1 \mu \mathrm{m}$ in size that require the hosts cell to
\end{tabular}
replicate)

Adenoviruses

Hepatitis A virus

Hepatitis E virus

Norovirus and other caliciviruses

\section{Gastroenteritis}

Poliomyelitis, mild febrile illness,

Polioviruses and other enteroviruses myocarditis, meningitis, meningoencephalitis, herpangina, hand-foot-and-mouth disease

Progressive multifocal

Polyomavirus

Rotavirus and astrovirus hemorrhagic cystitis

Gastroenteritis

Palmar and plantar warts, common warts, flat warts, anogenital warts haemorrhagic cystitis, conjunctivitis

epatitis A (liver infection), acute liver failure (adults over 40)

Hepatitis E (liver infection), acute liver failure

Papillomavirus eukoencephalopathy,

Chronic respiratory disease

Allard and Vantarakis, 2017

or persistent infection

Chronic hepatitis E (Immunocompromised hosts)

Chronic gastroenteritis (immunocompromised hosts)

Polymyositis, dilated cardiomyopathy, chronic fatigue syndrome

Cancer

No evidence of chronic disease

da Silva et al., 2016

van der Poel and Rzezutka, 2017a

van der Poel and Rzezutka, 2017b

Bok and Green 2012

Katayama and

Vinjé, 2017 2016

Bofill-Mas, 2016
Betancourt and Shulmán,

\subsection{Bacteria}

Bacteria are unicellular prokaryotic organisms, which are characterized by the lack of a true nucleus and membrane-bound cell organelles such as mitochondria or chloroplasts. Most bacteria have a single circular chromosome, which is packed with double-stranded DNA. There are a variety of morphologies among bacteria, but three of the most common are bacillus (rod-shaped, e.g. Aeromonas, Escherichia coli), coccus (spherical, e.g. Staphylococcus aureus), or spirillum (helical rods, e.g. Arcobacter, Campylobacter, Helicobacter pylori). Bacteria vary in size from 0.2 to $2 \mu \mathrm{m}$.

Pathogenic bacteria, which represent only a small fraction of total bacteria in the environment, can be divided into two major groups based on their cell wall structures, which influence their Gram stain reaction: gram-positive and gram negative. Gram-positive bacteria appear purpleviolet and gram-negative bacteria appear pink after Gram staining. Most of the bacteria that cause waterborne illnesses are gram-negative bacteria include Aeromonas, Arcobacter, Campylobacter, pathogenic E. coli, Shigella, Helicobacter pylori, Leptospiria, Salmonella, Vibrio cholerae, and Yersinia (see Part Three, Section II. Bacteria). (Note: examples of pathogenic gram-positive bacteria are Bacillus and Staphylococcus aureus however these are not fecal-oral and are not considered waterborne pathogens). The diseases are described in Table 3. 
Table 3. Bacteria and examples of acute and chronic diseases they cause

\begin{tabular}{|c|c|c|c|}
\hline Pathogen & AcuteDisease(s) & Chronic Disease(s) & Reference \\
\hline
\end{tabular}

Gastroenteritis,
septicemia, wound
infection, respiratory
infection

Arcobacter

Enteritis, bacteremia

Gastroenteritis

jejuni,

Campylobacter

coli

Pathogenic

members of $E$.

coli

Shigella

Helicobacter

pylori

Gastritis, ulcer

Mild watery diarrhea,

severe dysentery

(shigellosis)

septicemia, meningitis, pneumonia, haemolytic uraemic syndrome (acute renal failure and haemolytic anaemia)

Reactive arthritis

Guillain-Barré syndrome (a post-infectious autoimmune disorder of the peripheral nervous system), postinfectious irritable bowel syndrome and inflammatory bowel disease

Chronic kidney failure due to haemolytic uraemic syndrome

Garcia-Aljaro et al., 2017

Garcia-Aljaro et al., 2017

Chronic gastritis, mucosaassociated lymphoid tissue (MALT) lymphoma, nonHodgkin's lymphoma and gastric cancer

Araujo Boira and Hanninen, 2017

Chronic sequel of leptospirosis has been recognized

Levett, 2001

Salmonellosis

Salmonella

(gastroenteritis, enteric fever, septicemia)

Vibrio cholerae

Cholera, acute watery diarrhea

Acute enteritis
Reactive arthritis

CDC, 2018a

No evidence of chronic disease

CDC, 2014

Reactive arthritis

CDC, 2016 
Some pathogenic bacteria such as Aeromonas, pathogenic members of E. coli, Salmonella and Vibrio cholerae have substantial environmental reservoirs. Members of the genus Aeromonas are ubiquitous in water environments (both freshwater and seawater) and wastewater. Certain pathogenic strains of Aeromonas cause diseases in human, ranging from subclinical conditions such as gastroenteritis to severe conditions including wound infections and septicemia. Aeromonas has also been shown to be a cause of infections associated with natural disasters such as hurricanes, tsunamis and earthquakes (Janda and Abbott, 2010). Both pathogenic E. coli and Salmonella also infect other animals and therefore have animal reservoirs and the spread of these pathogens among human populations, particularly in developed countries, is primarily mediated via foods contaminated by animal products (NRC, 2004). Vibrio cholerae, with strains that cause cholera, still remains a global threat to public health and is usually restricted to developing regions where drinking water and feces or wastewater treatment and disposal are poor. But Vibrio also has an environmental reservoir in the marine environment and can replicate in zooplankton. Cholera is characterized by an acute diarrheal infection and dehydration usually in epidemic outbreaks (Barzilay et al., 2013). Vibrio cholera is usually found in water or food sources in areas where the disease is endemic and have been contaminated by feces from an individual infected with cholera.
Besides pathogenic bacteria, some bacteria have been used as "indicators" of fecal pollution (see Part Two: Indicators and Microbial Source Tracking Markers). This includes fecal coliforms, E. coli, enterococci and Clostridium perfringens. These fecal indicator bacteria are usually non-pathogenic and are natural inhabitants of the gastrointestinal tracts of humans and other warm-blooded animals. They are released into the environment with human and animal feces. E. coli is the universal indicator used to address the quality of ambient waters, groundwater and treated waters in both developed and developing countries.

\subsection{Protists}

Protists are eukaryotic organisms which means they actually belong to the animal kingdom. Their DNA is enclosed in a nucleus inside the cell. They have organelles and can undergo either simple replication (growing and splitting) or complex sexual replication. Protists are mostly microscopic ranging in size from 10 to $200 \mu \mathrm{m}$. They are diverse in form and examples include plant-like protists (the algae), fungus-like protists (the slime molds) and animal-like protists (the protozoa). Many protists, particularly protozoa are pathogens that are obligate parasites that must infect other organisms to survive and propagate. Most protozoa transmitted via water are gastrointestinal pathogens that cause nausea, abdominal cramps, vomiting, diarrhea and fever (Table 4).

Table 4. Protists and examples of acute and chronic diseases they cause

\begin{tabular}{ccc}
\hline Pathogen & Acute Disease(s) & Chronic Disease(s) \\
\hline Protists (single celled microscopic organisms in the animal kingdom, produce cysts or oocysts, range in size \\
from 10 to $200 \mu \mathrm{m}$, in feces as part of the life cycle within the hosts)
\end{tabular}

\section{Balantidium coli Balantidial dysentery (balantidiasis)}

Blastocystosis, diarrhea, abdominal pain. The role of

Blastocystis

Blastocystis in causing disease is unclear, a natural component of the human intestinal microbiota.
Cyclospora
cayetanensis
Diarrhea

Cryptosporidium spp. Cryptosporidiosis, diarrhea

Entamoeba histolytica Diarrhea, amoebic dysentery, amoebic colitis

Giardia duodenalis

Giardiasis, diarrhea

Microsporidia

Toxoplasma gondii

Opportunistic disease, microsporidiosis, diarrhea

Toxoplasmosis, severe neurological disorders,
Chronic disease sometimes occurs,

characterized by intermittent diarrhea, Ponce-Gordo and Jirku-

Chronic cryptosporidiosis retinochoroiditis cramping rectal pain, nausea and vomiting

Blastocystis has been associated with the irritable bowel syndrome

de la Cruz and Stensvold,

2017

Chronic diarrhea (immunocompromised hosts), various sequelae including biliary disease, acalculous cholecystitis,

Guillain-Barré syndrome and Reiter syndrome. (immunocompromised hosts)

Chronic amoebic colitis, amoebama

Chronic giardiasis (immunocompromised hosts)

Pomajbíková, 2017

Chacin-Bonilla, 2017

Hunter and Nichols, 2002

Ben Ayed and Sabbahi, 2017

Boarato-David et al., 2016

Severe enteritis (chronic diarrhea, dehydration, weight loss), bronchitis

Feng and Li, 2017

Infection persists lifelong in the form of tissue cysts in immunocompromised Bahia-Oliveira et al., 2017 hosts. 
The most prevalent protozoan parasites associated with waterborne disease are Cryptosporidium parvum and Giardia lamblia. They form hardy oocysts (Cryptosporidium) and cysts (Giardia) that can survive outside a host and are excreted in the feces of infected individuals. (Oo)cysts are very persistent in water and resistant to the disinfectants commonly used in drinking water treatment. Cryptosporidium along with enterotoxigenic E.coli, Shigella and rotavirus have been shown to be the leading causes of moderate-to-severe diarrheal disease in children subSaharan Africa and South Asia (Kotloff et al., 2013).

Microsporidia are obligate spore-forming parasitic fungi with the spore is the only environmentally stable and infective form. Although microsporidia are associated primarily with infections of the intestinal tract, dissemination to ocular, genitourinary and respiratory tracts may occur in immunocompromised individuals (Didier et al., 2004).

Cyclospora cayetanensis and Toxoplasma gondii are parasitic protozoa which the oocysts (unlike other parasitic protozoa such as Cryptosporidium) are not infectious upon excretion and require a maturation phase in the environment that is on the order of days. Toxoplasma gondii has wild and domestic felines as its host but can also infect humans and other animals due to the ingestion of oocysts from feline feces (Figure 2).

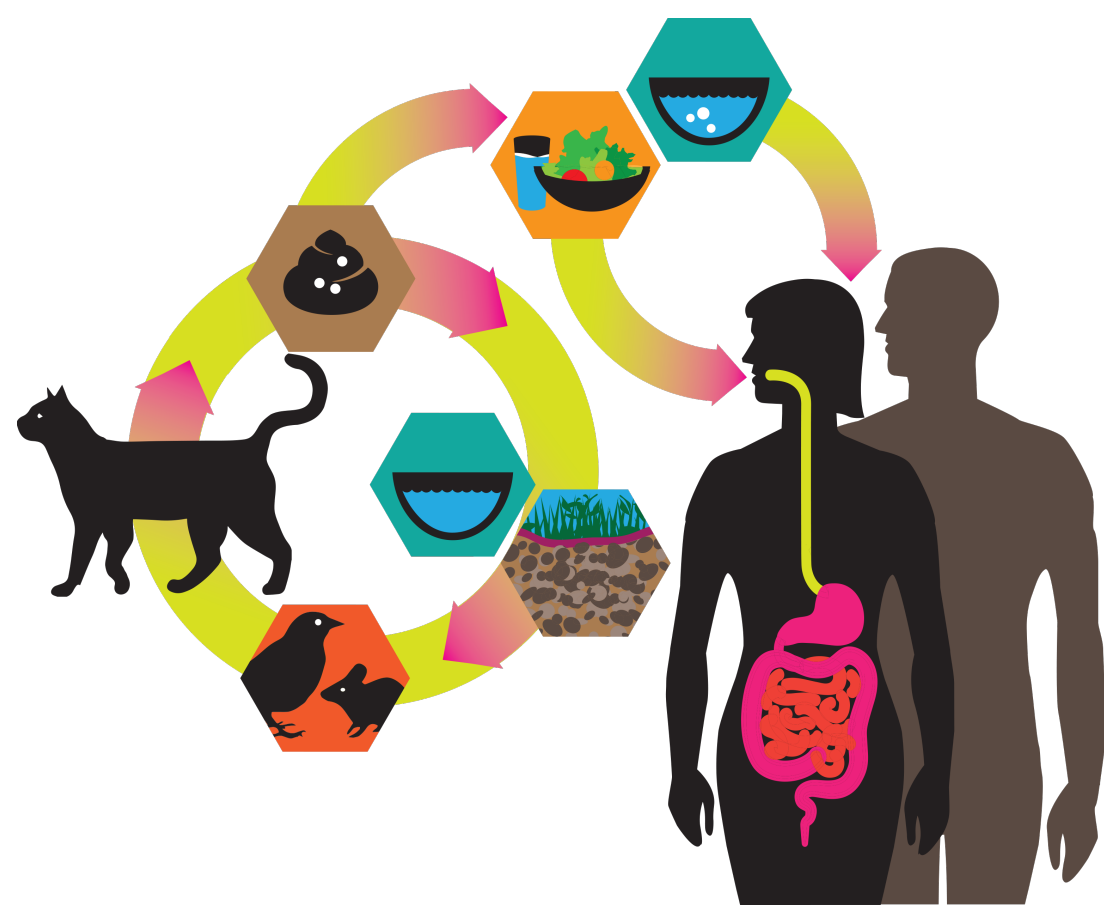

Intermediate hosts (include birds \& rodents) in nature become infected after ingesting soil, water or plant material contaminated with oocysts. Cats then become infected after consuming intermediate hosts harboring tissue cysts or directly ingesting sporulated oocysts.

See https://www.cdc.gov/parasites/toxoplasmosis/ biology.html for detailed life cycle.

Figure 2. Toxoplasma gondii exposure cycle (Created by Design2 for the GWPP) 


\subsection{Helminths}

Helminths, also commonly known as parasitic worms, are multicellular complex organisms containing organ and tissue. They belong to the Kingdom Animalia and include cestodes (tapeworms), nematodes (or roundworms) and trematodes (or flukes). The classification of helminths is based on the external and internal morphology of egg (also referred to as ova), larval and adult stages and their life cycles.

Cestodes are flat, hermaphroditic, having both male and female reproductive organs, worms that colonize the human gastrointestinal tract. Adult tapeworms are 5 to 10 $\mathrm{m}$ long. Some cestodes are primarily human pathogens such as Taenia spp., others are animal pathogens that also infects humans (Echinococcus spp. and Diphyllobothriidae).

Nematodes are cylindrical in structure and bisexual. Examples of nematodes include Toxocara spp. and soiltransmitted helminths (Ascaris spp., Trichuris trichiura and hookworms).

Trematodes are leaf-shaped flatworms and vary in length from a few millimeters to $8 \mathrm{~cm}$. Trematodes are hermaphroditic, except blood flukes (Schistosoma spp.), which are bisexual. Other examples of trematodes include Fasciola spp., Paragonimus, intestinal flukes (Heterophyidae and Echinostomatidae) and liver flukes (Clonorchis sinensis, Opisthorchis spp., and Metorchis spp.).

Helminths infect a large number of people and animals worldwide, particularly in developing regions where sanitation and hygiene conditions are poor (De Silva et al., 2003). Adverse health effects due to heavy helminth infestations include abdominal pain, diarrhea, blood and protein loss, intestinal blockage, rectal prolapse, and impairment of physical and mental development in children (Sobsey, 2015) (Table 5). Several helminths including Echinococcus spp., Fasciola spp. Schistosoma spp. and soiltransmitted helminths are major causes of neglected tropical diseases, which cause substantial illness for more than one billion people in tropical and subtropical regions according to the World Health Organization. Although helminth infections are treatable, reinfection can occur due to the lack of Water, Sanitation and Hygiene (WASH) facilities (Freeman et al., 2013). 
Table 5. Helminths and examples of acute and chronic diseases they cause

Pathogen $\quad$ Acute Disease(s) $\quad$ Chronic Disease(s) $\quad$ Reference

Helminths (classified as various type of worms which produce eggs which are excreted in the faeces, multicellular organisms, vary in length from 2 to $3 \mathrm{~mm}$ to $10 \mathrm{~m}$, are visible to the naked eye in their adult stages, infect definitive hosts)

\section{Cestodes}

\begin{tabular}{ccc}
\hline Diphyllobothriidae & $\begin{array}{c}\text { Diphyllobothriasis, diarrhea, weight } \\
\text { loss, vitamin B12 deficiency with } \\
\text { pernicious anemia, cholecystitis }\end{array}$ & $\begin{array}{c}\text { Diphllobothriasis can be a long-lasting } \\
\text { infection (decades). }\end{array}$ \\
\hline
\end{tabular}

Echinococcus spp. Acute echinococcosis

Taenia spp.
Taeniasis (digestive problem, abdominal pain, loss of appetite, upset stomach)
Cystic echinococcosis (as a cyst in liver or lung), alveolar echinococcosis (as a pseudo-tumor in liver)

Di Comite et al., 2000; Vuitton et al., 2017

Cysticercosis (seizures and muscle or eye damage, caused by T. solium tapeworm)

\section{Trematodes}

Clonorchis sinensis, Opisthorchis spp., and Metorchis spp.

The Liver Flukes

Fasciola spp. and Fasciolopsis buski

Intestinal flukes: Heterophyidae and Echinostomatidae

Paragonimus spp.

Schistosoma spp.
Acute phase (last from 2 to 4 months): dyspepsia, nausea, vomiting, abdominal pain, high fever
Chronic inflammatory diseases of the hepatobiliary system, may lead to bile duct cancer
Murell and Pozio, 2017

Chronic phase (after months to years of infection): painful liver enlargement, obstructive jaundice, chest pain, weight loss, cholelithiasis, hepatic lesions,

fibrosis and chronic inflammation of the bile ducts

Echinostomiasis (diarrhea, abdominal pain, catarrhal inflammation), heterophyiasis (diarrhea, colicky abdominal pain)

Diarrhea, abdominal pain, fever, chest pain, fatigue

Intestinal schistosomiasis (hepatosplenomegaly, fever, abdominal pain, bloody diarrhea), urinary schistosomiasis (dysuria, haematuria)

\section{Chronic diarrhea}

CDC, 2017; CDC, $2018 \mathrm{a}$

Pulmonary paragonimiasis, cerebral paragonimiasis

Liver fibrosis, portal hypertension, bladder cancer, renal failure, anaemia, malnutrition, impaired growth and poor cognition in children

CDC, 2015

CDC, 2012b
CDC, 2013b

Ascaris spp.

Abdominal discomfort

\section{Nematodes}

Itching and a localized rash,

Hookworms abdominal pain, diarrhea, loss of appetite, weight loss, fatigue, anemia

Toxocara spp.

Acute infection is asymptomatic

Trichuris trichiura

Trichuriasis (watery, mucus-laden, bloody, painful diarrhea)
CDC, $2018 \mathrm{~b}$

Intestinal blockage, impair growth in children

Can affect the physical and cognitive growth of children

CDC, 2013c

Ocular toxocariasis (vision loss, eye inflammation or damage to the retina), Visceral toxocariasis (fever, fatigue, coughing, wheezing, or abdominal pain)

Rectal prolapse, severe anemia, growth retardation and impaired cognitive development in children
CDC, 2013d

CDC, $2013 e$ 
Nematodes such as Trichuris trichiura, Ascaris spp. and hookworms are important fecal-oral helminths which can be present as eggs in human feces that have been deposited on the ground and can persist in moist soils for years. The fecally excreted eggs mature in the soil and this takes days to weeks depending on the helminth and environmental conditions. Human can expose to the helminths by either penetrating of mature helminth larvae to the skin when come in contact with contaminated soil or by ingesting of mature eggs in contaminated food and water. Many other helminths are regarded as agents of water-based disease because they have life cycles involving water, although the final transmission to humans is primarily through the consumption of uncooked or undercooked food such as fish. Schistosoma species are parasitic flukes that have a life cycle involving only water.

\subsection{Factors Affecting Environmental Transmission of Pathogens}

Many factors affect the ability of a pathogen to be transmitted through the environment that represents a potential risk of host exposure, infection and disease. First, the pathogen must enter the environment and for waterassociated pathogens, they enter the environment via human or animal feces (urine for Leptospira and Schistosoma) deposited on land or in water. Thus the loading and concentrations of pathogens are of great importance. Once the pathogen is in the environment, several factors affect the ability of the pathogen to be transmitted to a human or animal host. The pathogen must infect new susceptible hosts by entering their body in order to survive. In this section, these factors are divided into pathogen characteristics and environmental factors. Table 6 compares the groups of pathogens and their relative risks associated with these factors.

Table 6. Relative risks associated with pathogen groups and their characteristics

\begin{tabular}{|c|c|c|c|c|}
\hline $\begin{array}{l}\text { Pathogen } \\
\text { Group }\end{array}$ & Excretion in Feces and Sewage & Persistence & Potency & Zoonotic \\
\hline Viruses & $\mathrm{H}$ (high) & M (medium) & $\mathrm{H}$ & L (low) \\
\hline Bacteria & $\mathrm{H}$ & $\mathrm{L}$ & M & $\mathrm{H}$ \\
\hline Protists & M & M & M-H & $\mathrm{H}$ \\
\hline Helminths & $\mathrm{L}$ & $\mathrm{H}^{\mathrm{a}, \mathrm{b}}$ & $\mathrm{H}^{\mathrm{c}}$ & $\mathrm{H}$ \\
\hline
\end{tabular}

${ }^{a}$ It is presumed that persistence can be years due to reservoirs and stability of various life stages, yet very little survival data available.

${ }^{\mathrm{b}}$ Helminth eggs go through a period of latency. Latency is the period of time between the excretion of the pathogen and the time that it is infective to a new susceptible host.

${ }^{c}$ No dose-response data available in humans. This is a presumption that exposure to low doses can initial infections.

\subsection{Pathogen Characteristics}

4.1.1 Multiplication and the infectious/life cycle of pathogens

Some pathogens can regrow or multiply in the environment and may reach high concentrations under favorable conditions. For example, Salmonella has been shown to multiply in biosolids and biosolid-amended soil (Zaleski et al., 2005). This ability to grow and multiply within diverse environmental matrices is unique to bacteria. However, viruses and protozoa, which are obligate parasites, cannot multiply in the environment, but are able to persist.
Most of the helminths have complex infectious or life cycles in the environment, which means they require more than one host (intermediate host and definitive host) in series to complete the life cycle (Table 7). In this case, the intermediate host is usually an animal infected by a larval or asexual form of the helminths. The definitive host is a human or animal infected with the adult or sexual form of the helminths. For most helminths of importance in sanitation, humans produce the eggs in their feces (this is part of the reproductive life cycle which happens in the definitive host). The eggs are produced in a form which are not immediately infectious, non-embryonated or immature and they must mature in the environment. This process is known as latency (see section 4.1.2). 
Table 7. Features of key latent ${ }^{\mathrm{a}}$ helminths who have complex life cycles

\begin{tabular}{|c|c|c|c|c|}
\hline $\begin{array}{c}\text { Latent } \\
\text { Helminths }\end{array}$ & $\begin{array}{l}\text { Range of Days Prior to } \\
\text { Becoming Infectious }\end{array}$ & First Intermediate Host ${ }^{b}$ & $\begin{array}{c}\text { Second Intermediate } \\
\text { Host }\end{array}$ & Definitive Host $^{c}$ \\
\hline \multicolumn{5}{|c|}{ Cestodes } \\
\hline $\begin{array}{l}\text { Echinococcus } \\
\text { granulosus }\end{array}$ & 28 to 49 & $\begin{array}{l}\text { Sheep, goat, swine, cattle, } \\
\text { horses, camel }\end{array}$ & None & $\begin{array}{l}\text { Dog and other } \\
\text { canids, Fox, and } \\
\text { to a lesser extent } \\
\text { dog, cat, coyote } \\
\text { and wolf }\end{array}$ \\
\hline $\begin{array}{l}\text { Echinococcus } \\
\text { multilocularis }\end{array}$ & 28 to 49 & Rodent & None & $\begin{array}{c}\text { Dog and other } \\
\text { canids, Fox, and } \\
\text { to a lesser extent } \\
\text { dog, cat, coyote } \\
\text { and wolf }\end{array}$ \\
\hline $\begin{array}{l}\text { Diphyllobothrium } \\
\text { latum }\end{array}$ & 18 to 20 & Freshwater crustacean & Freshwater fish & $\begin{array}{l}\text { Humans, other } \\
\text { mammals }\end{array}$ \\
\hline $\begin{array}{l}\text { Taenia saginata } \\
\text { (beef measles } \\
\text { worm) }\end{array}$ & $\begin{array}{l}\text { Eggs can survive for days to } \\
\text { months in the environment }\end{array}$ & Cattle & None & Humans \\
\hline $\begin{array}{l}\text { Taenia solium } \\
\text { (pork measles } \\
\text { worm) }\end{array}$ & $\begin{array}{l}\text { Eggs can survive for days to } \\
\text { months in the environment }\end{array}$ & Pig & None & Humans \\
\hline \multicolumn{5}{|c|}{ Nematodes } \\
\hline Toxocara canis & 14 to 28 & Dog & None & Humans \\
\hline Toxocara cati & 14 to 28 & Cat & None & Humans \\
\hline \multicolumn{5}{|c|}{ Trematodes } \\
\hline
\end{tabular}

The Liver Flukes:

Clonorchis

sinensis,

Opisthorchis spp.,

and Metorchis

spp.

$\begin{array}{llll}\begin{array}{l}\text { Schistosoma spp. } \\ \text { Fasciola spp. and } \\ \text { Fasciolopsis buski }\end{array} & \text { No data } & \text { Freshwater snail } & \text { None } \\ \text { Paragonimus spp. } & \text { No data } & \text { Freshwater snail } & \text { Aquatic vegetation } \\ & \text { Freshwater snail } & \begin{array}{c}\text { Crustacean such as a crab } \\ \text { or crayfish }\end{array}\end{array}$

Intestinal Flukes:

Heterophyidae

and

No data

Freshwater snail

Fresh water fish

Humans, dog, pig, cat, mouse, camel

Humans, dog, cat, rodent, pig, horse and goat

Humans, herbivores (sheep, cattle)

Humans, pig, dog, and a variety of feline species

Humans, fisheating mammals (e.g., cats and dogs) and birds

Echinostomatidae

${ }^{\text {a } E x i s t i n g, ~ b u t ~ n o t ~ y e t ~ d e v e l o p e d ~ o r ~ i n f e c t i o u s ~}$

${ }^{b}$ Intermediate host: The host harboring a parasite that primarily grows but no sexual reproduction occurs and often acts as vector of the parasite in reaching its definitive host (where it will become mature).

${ }^{\mathrm{c}}$ Definitive host: The host where the parasite spends its final development stage and reaches its mature form and reproduces sexually. Produces the eggs in the feces. 
Helminths (the worms) have a much more complex exposure cycle which often involves:

- An immature form of the egg which is not infectious termed unembryonated egg is excreted in feces and the egg must mature in the environment to be infectious.

- Other animals including snails and fish which are involved in the exposure and lifecycle of the parasite.

- Other definitive hosts (that host which excretes the eggs of the parasite in it's feces).

Figures 3 to 5 show exposure cycles for the Cestodes (Diphyllobothriidae, Echinococcus and Taenia)

\section{Diphyllobothrium}

Common name: Fish or Broad Tapeworm

Humans are the definitive host as well as other mammals.

Unembryonated eggs are passed in feces and can end up in sewage and sludge, but must make their way into water.

Eggs embryonate (become infective) in water and within 18 to 20 days eggs mature.

Eggs hatch in the water and the coracidia (the next life stage) are ingested by freshwater crustaceans (first intermediate host) and develop into proceroid larve. Then small fish (second intermediate host) eat the crustaceans, then these can be eaten by larger predator species (e.g. trout, perch, walleyed pike). In this case, the sparganum can migrate larger predator fish, into the flesh of the fish and develop into plerocercoid larvae.

Exposure occurs when the infective ploerocercoid larvae (sparganum) within the fish are ingested by humans.

Inside the host: After humans ingest the infected fish, the pleroceroid develop into immature adults and then into mature adult tapeworms which will reside in the small intestine.

Immature eggs are discharged from the reproductive organs of the tapeworm (proglottids) and and are passed in the feces 5 to 6 weeks after infection.

See https://www.cdc.gov/parasites/ diphyllobothrium/biology.html for the detailed lifecycle.

Figure 3. Diphyllobothrium exposure cycle (Created by Design2 for the GWPP) 


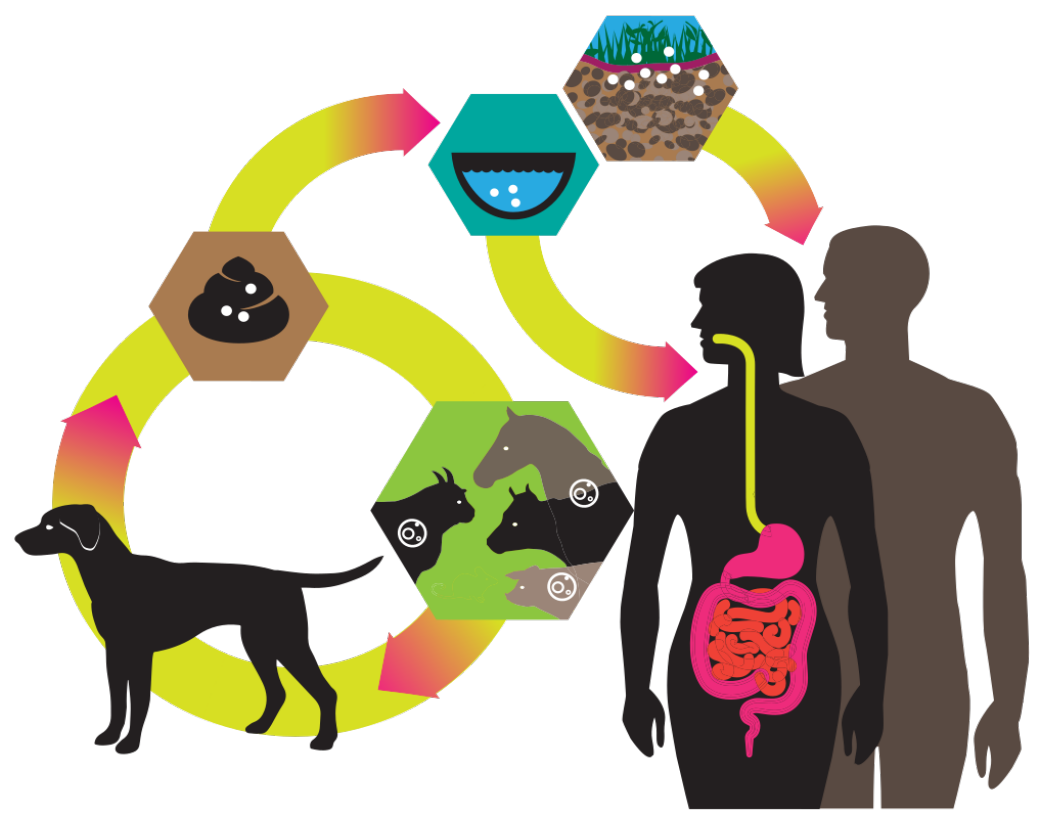

Echinococcus ${ }^{1}$

Common name: Tapeworm

Dogs are the definitive host. Humans acquire the infection as accidental hosts.

Mature and infective eggs are passed in the dog's feces.

Eggs can survive for long periods of time (up to 200 days) in moist soil and optimal temperatures.

Exposure occurs when infective eggs from dog feces are swallowed by humans due to contaminated hands, food and untreated water.

Humans are accidental hosts and cannot transmit the parasite / disease.

The full life cycle for dogs: Dog's become infected by ingesting cyst-containing organs (uncooked) of the infected intermediate host. [Eggs hatch in the intermediate hosts (e.g. sheep, goats, swine, cattle, horses, cattle) in the small bowel. Parasites migrate through the circulatory system into various organs (esp. liver and lungs) where they develop into cysts].

After 32 to 80 days, the parasites develop into adults that produce more eggs that are deposited into the feces of the dog.

See https://www.cdc.gov/parasites/echinococcosis/ biology.html for detailed life cycle.

${ }^{1}$ E. granulosus

Figure 4. Echinococcus exposure cycle (Created by Design2 for the GWPP)

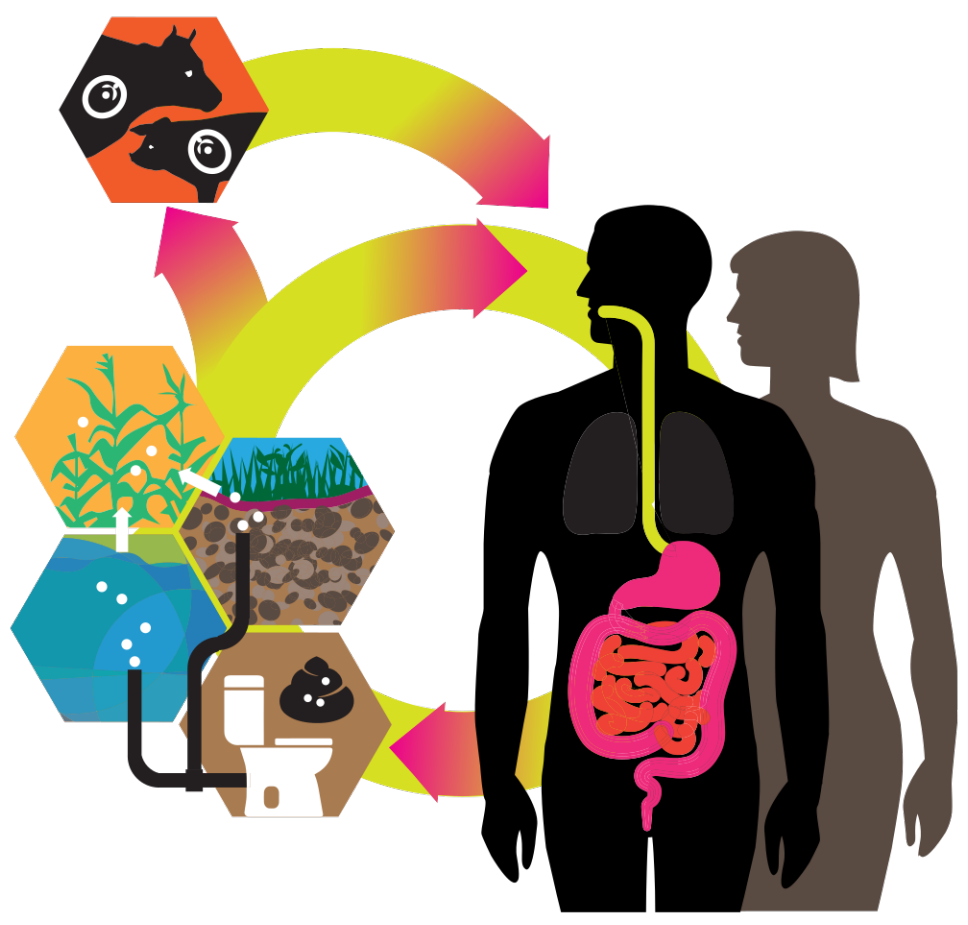

Taenia spp.

Common names: Pig Tapeworm and Beef Tapeworm Humans are the definitive host.

Mature eggs are passed in the feces and can end up in sewage and sludge.

Eggs may survive days to months in the environment.

Exposure occurs when infective eggs of the T.solium (Pig tapeworm) are ingested by humans often due to contaminated hands, food and untreated water.

Cattle and pigs also become infected by ingesting vegetation contaminated with eggs

Oncospheres hatch in the animal intestine and invade the intestinal wall, migrate to striated muscles where they develop into cysticerci. A cysticercus can survive for several years in the animal.

Other routes of exposure occurs when humans ingest raw or undercooked infected meat.

Inside the host: The cysticerus develops over 2 months in the human intestine. The adult tapeworms produce proglottids which mature and migrate to the anus, producing eggs which are passed with the feces.

See https://www.cdc.gov/parasites/taeniasis/biology.html for detailed life cycle.

Figure 5. Taenia exposure cycle (Created by Design2 for the GWPP) 
Figures 6 to 9 show exposure cycles for the Nematodes (Ascaris, Hookworms, Toxocara and Trichuris). Toxocara does not involve fecal excretion from humans but from dogs similar to the one protozoan Toxoplama mentioned above which is excreted into environment from cat fees.

\author{
Ascaris lumbricoides \\ Common name: Roundworm
}

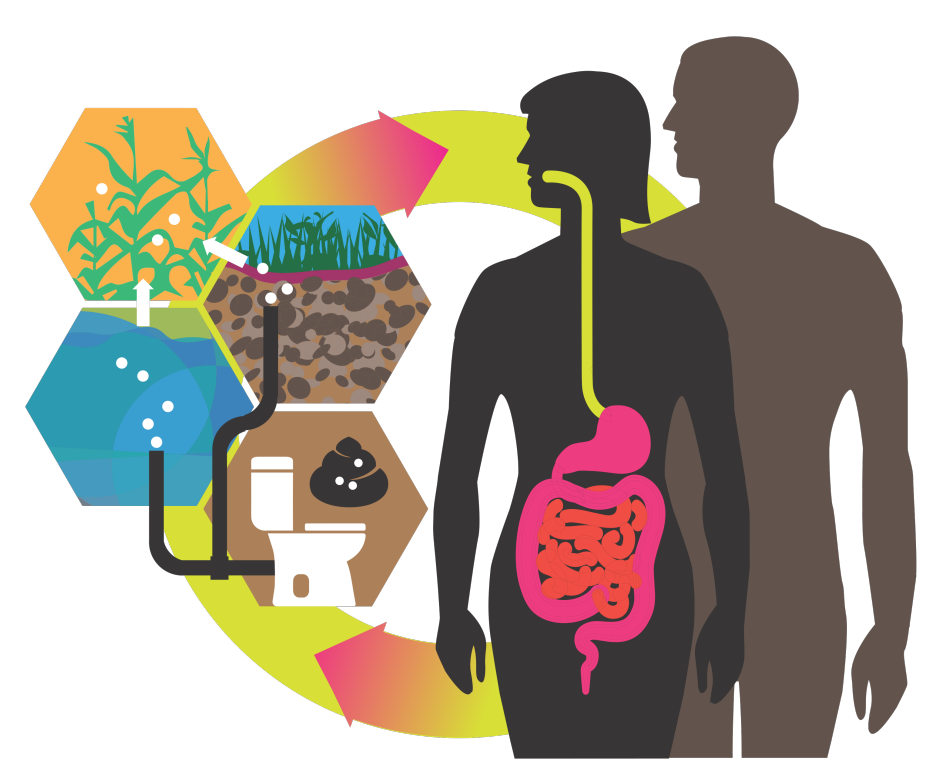

Humans are the definitive host.

Unembryonated eggs are passed with the feces and can end up in sewage and sludge.

After being excreted the fertilized eggs embryonate and become infective after 18 days to several weeks.

Optimum environmental conditions are moist, warm and shaded soil. The eggs can survive in soils up to 10 years.

Exposure occurs when infective eggs are swallowed often due to contaminated hands, food and untreated water.

Inside the host: The larvae hatch and invade the gut mucosa and travel via the circulatory system through the liver and heart to the lungs, penetrate the capillaries and enter the aveloli of the lungs initiating an inflammatory response. The larvae mature further in the lungs (10 to 14 days), ascend the bronchial tree to the throat and are swallowed.

Upon reaching the small intestine, they develop into adult worms. Adult worms live in the lumen of the small intestine of humans. Between 2 to 3 months are required from ingestion of the infective eggs before the adult female worm can lay eggs inside the intestine.

Adult worms can live 1 to 2 years in the body.

See http://www.cdc.gov/parasites/ascariasis/ biology.html for detailed life cycle.

Figure 6. Ascaris exposure cycle (Created by Design2 for the GWPP)

\title{
Ancylostoma Necator
}

Common name: Hookworms

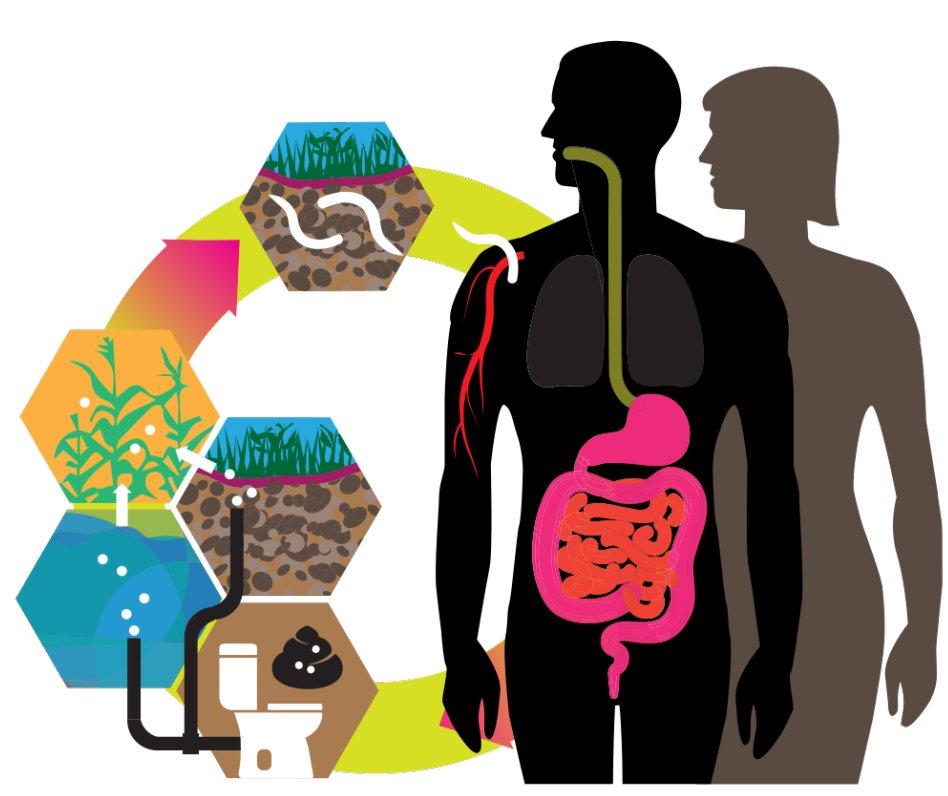

Humans are the definitive host.

Unembryonated eggs are passed in the feces and can end up in sewage and sludge and ultimately in soil and water.

After being excreted the eggs hatch producing larvae (rhabditiform) in 1 to 2 days in feces and soil, favorable conditions include moisture, warmth, and shade.

The released rhabditiform larvae after 5 to 10 days become filiform larvae that are infective. These infective larvae can survive 3 to 4 weeks in favorable environmental conditions.

Exposure occurs when the infective larvae penetrates the skin via human contact with contaminated soil or water.

Inside the host: The larvae are carried through the blood vessels to the heart and then to the lungs. They penetrate into the pulmonary alveoli, ascend the bronchial tree to the pharynx, and are swallowed.

The larvae reach the small intestine, where they reside and mature into adults to lay eggs. Adult worms live in the lumen of the small intestine, where they attach to the intestinal wall with resultant blood loss by the host.

Most adult worms live up to 2 years (may then be eliminated, 1 to 2 years, but the longevity could reach several years).

See https://www.cdc.gov/parasites/hookworm/biology.html for detailed lifecycle.

Figure 7. Hookworms exposure cycle (Created by Design2 for the GWPP) 


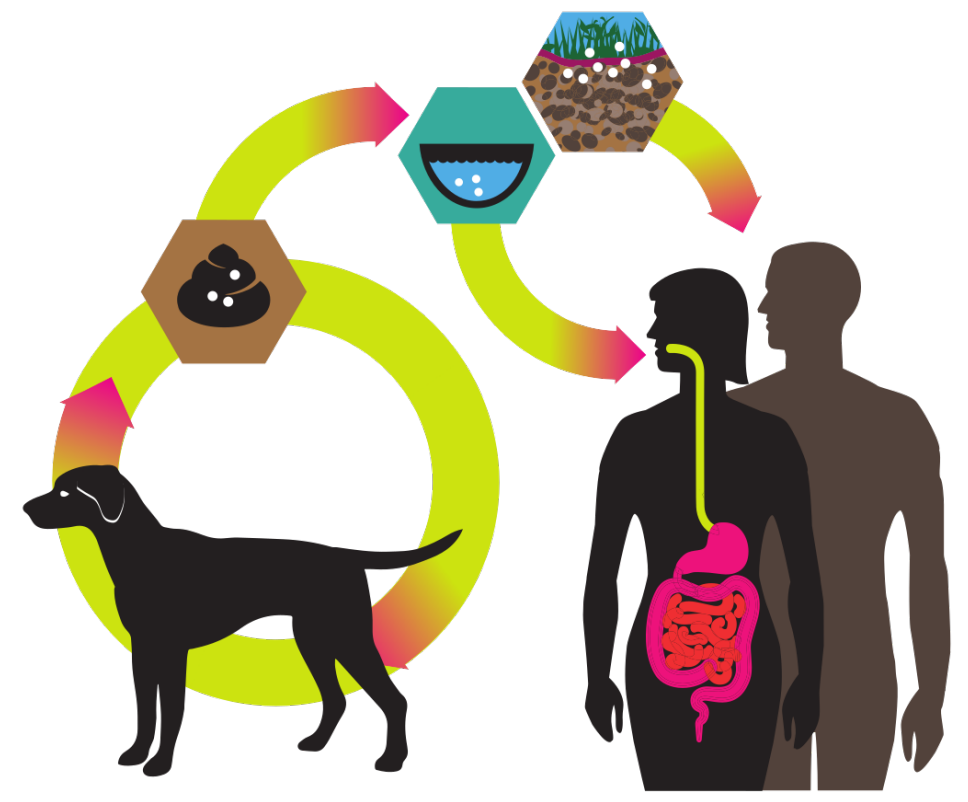
are accidental hosts). The eggs ingested by paratenic hosts hatch and larvae penetrate the gut wall and migrate into various tissues where they encyst.

The lifecycle is complete when dogs eat these hosts and the larvae develop into egg-laying adult worms in the small intestine.

See https://www.cdc.gov/parasites/toxocariasis/biology.html for detailed lifecycle.

${ }^{1}$ Toxocara canis

Figure 8. Toxocara exposure cycle (Created by Design2 for the GWPP)

Trichuris trichiura

Common name: Human Whipworm

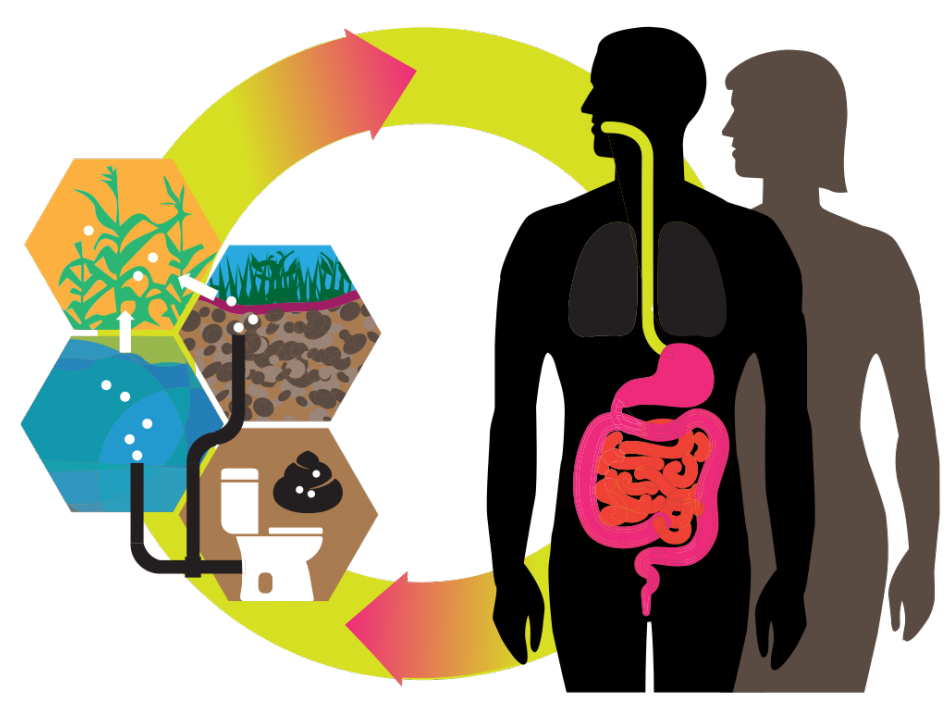

Humans are the definitive host.

Unembryonated eggs are passed with the feces and can end up in sewage and sludge.

After being excreted the fertilized eggs embryonate and become infective in the soil or sludge after 15 to 30 days. Optimum environmental conditions are moist, warm and shaded soil. The eggs can survive in soils up to 10 years.

Exposure occurs when infective eggs are ingested by humans due to contaminated hands, food or untreated water.

Inside the host: The eggs hatch in the small intestine, and release larvae that mature and establish themselves as adults in the colon. The adult worms live the cecum and ascending colon. The life span of the adults is about 1 year.

See https://www.cdc.gov/parasites/whipworm/ biology.html for detailed lifecycle. 
Figures 10 to 14 show exposure cycles for the Trematodes (Liver flukes: eg Clonorchis as well as Fasciola hepatica; the Intestinal Flukes eg. Heterophyidae; the lung fluke Paragonimus and blood flukes Schistosoma).

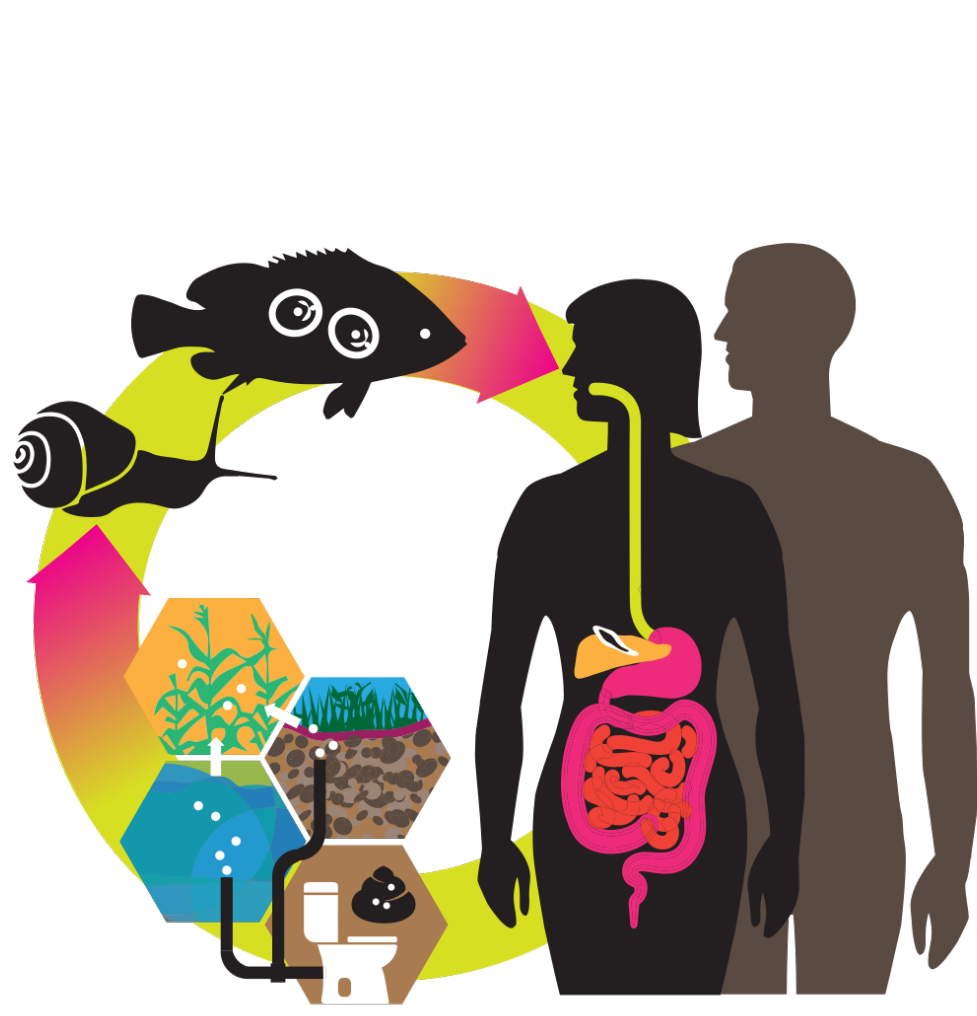

\section{Clonorchis sinensis, Opisthorchis spp., and Metorchis spp.}

Common name: Fishborne Liver Flukes

Humans are the definitive host along with other carnivorous animals.

Mature and infective eggs (with fully-developed miracidia) are passed with feces and can end up in sewage or sludge but must make their way to water.

Eggs can survive in cool water up to 160 days.

Eggs are ingested by a suitable snail host (first intermediate host), where they release miracidia that go through several developmental stages. Cercaria are then released into the water where they penetrate the flesh of freshwater fish (second intermediate host) and encyst as metacercariae.

Exposure occurs when humans ingest infectious metacercariae found in undercooked or salted, pickled or smoked fish.

Inside the host: After ingestion, the metacercariae excyst in the duodenum, ascend into the biliary tract, where they mature into adult flukes and produce eggs in about one month.

See https://www.cdc.gov/parasites/clonorchis/biology.html for detailed life cycle.

Figure 10. The liver flukes exposure cycle (Created by Design2 for the GWPP)

\section{Fasciola spp.}

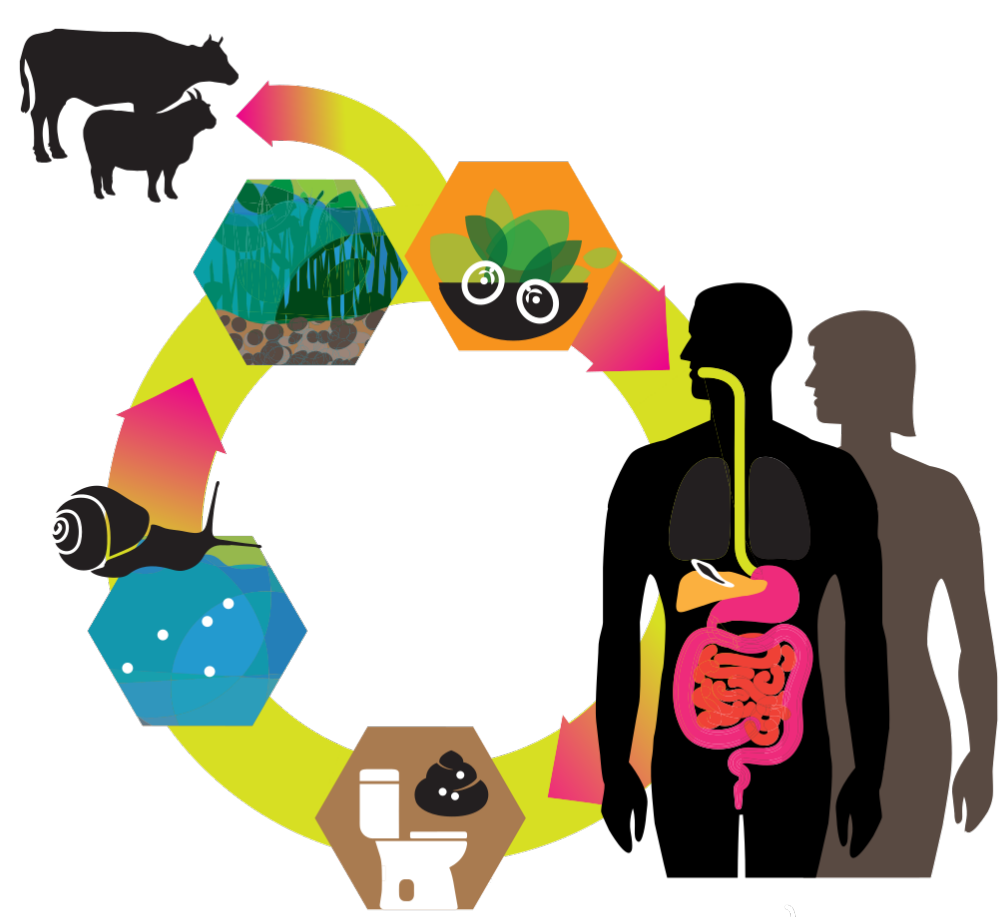

Common name: Common Liver Fluke

Humans are the definitive host.

Unembryonated eggs are discharged from the biliary ducts and passed with feces and can end up in sewage and sludge, but must make their way to water.

Eggs become embryonated (infectious) in water after 11 to 14 days and release miracdia that invade a suitable aquatic snail host (intermediate host).

In the snail, the parasites undergo several developmental stages and many cercariae are released from each miracidium from the snail and encyst as metacercariae on aquatic vegetation or other surfaces.

Exposure occurs when humans ingest the infectious metacercariae on plants.

Other mammals (often sheep and cattle) also acquire the infection by eating vegetation containing metacercariae.

Inside the host: After ingestion, the metacercariae excyst in the duodenum and migrate into the biliary ducts where they develop into adults. In humans, maturation into adult flukes takes approximately 4 months.

See https://www.cdc.gov/parasites/fasciola/biology.html for detailed lifecycle.

Figure 11. The Fasciolid trematodes exposure cycle (Created by Design2 for the GWPP) 


\section{Heterphyidae and Eschinostomatidae}

Common name: Intestinal Flukes

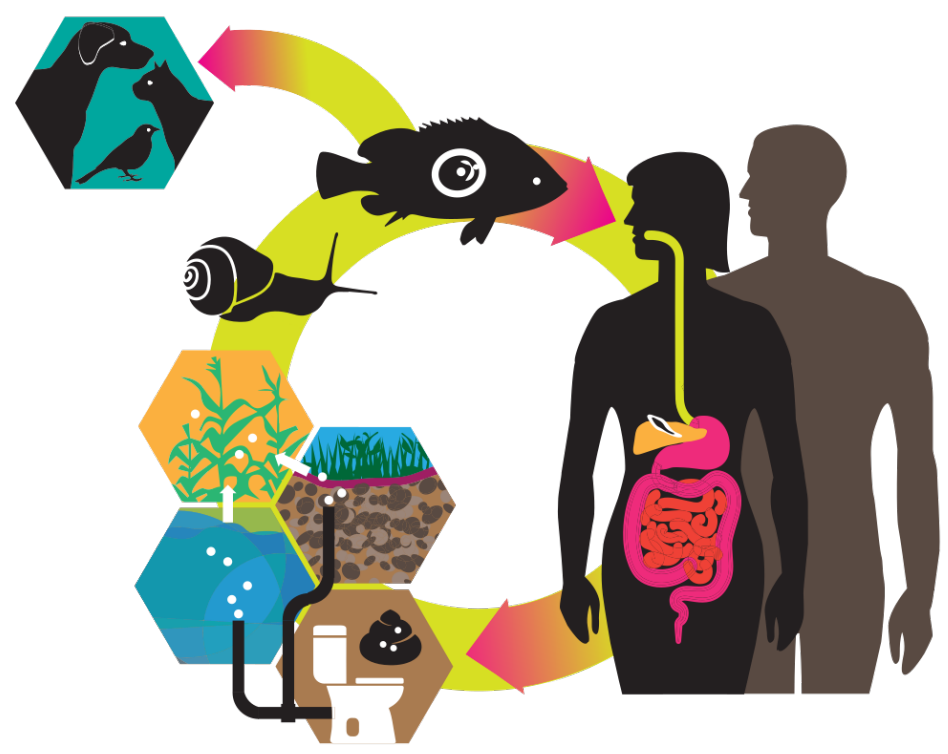

Humans are the definitive host.

Mature and infective eggs (with fully-developed miracidia) are passed with feces and can end up in sewage or sludge but must make their way to water.

Eggs are ingested by a suitable snail host (first intermediate host), where they release miracidia that go through several developmental stages. Cercariae are then released into the water where they penetrate the flesh of fresh/brackish fish (second intermediate host) and encyst as metacercariae.

Exposure occurs when humans ingest infectious metacercariae found in undercooked or salted, pickled or smoked fish.

In addition to humans, various fish-eating mammals (e.g. cats and dogs) and birds can be infected.

Inside the host: The metacercariae excyst, attach to the mucosa of the small intestine and mature into adults.

See https://www.cdc.gov/parasites/heterophyiasis/ biology.html for detailed life cycle.

Figure 12. Heterophyidae and Echinostomatidae exposure cycle (Created by Design2 for the GWPP)

\section{Paragonimus spp.}

Common name: Lung Fluke

Humans are the definitive host as well as other mammals.

Unembryonated eggs are excreted in the sputum, or alternatively they are swallowed and passed with feces and can end up in sewage and sludge.

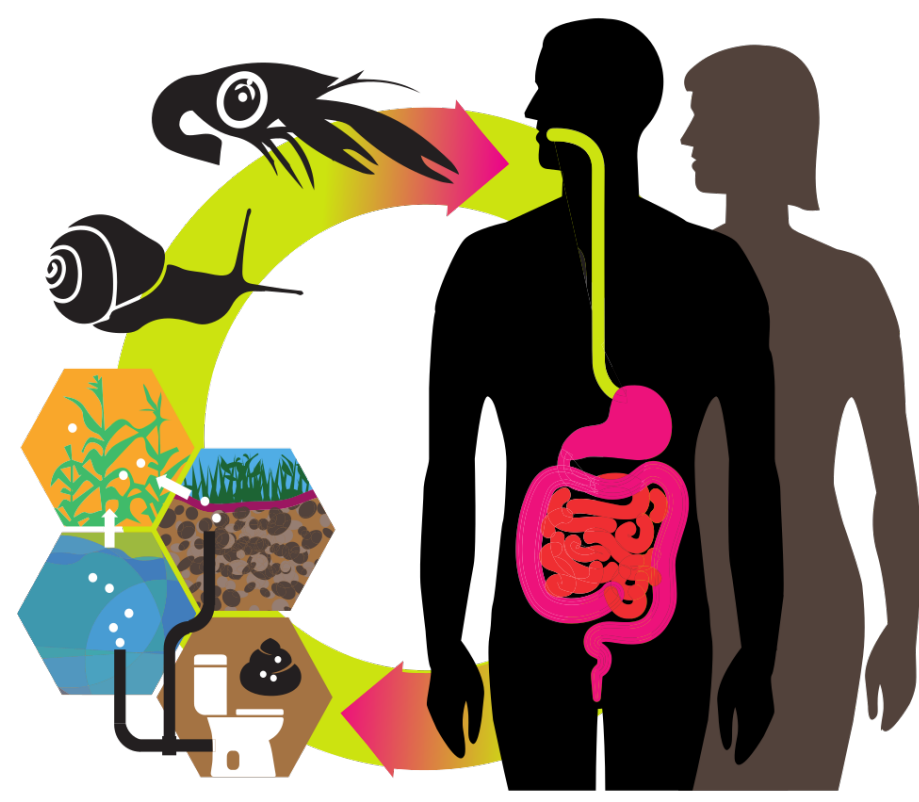

Eggs become embryonated (infective) after about 14 days in aerated water and miracidia hatch and infect a snail (first intermediate host). Miracidia go through several developmental stages inside the snail. Cercariae emerge from the snail.

The cercariae invade crustaceans such as crabs or crayfish (second intermediate host), where they encyst and become metacercariae. This is the infective stage for the mammalian host.

Exposure occurs when humans ingest the infectious metacercariae from inadequately cooked or pickled crab or crayfish that harbors the parasite.

Inside the host: The metacercariae excyst in the duodenum, penetrate through the intestinal wall into the peritoneal cavity, then through the abdominal wall and diaphragm into the lungs, where they become encapsulated and develop into adults. Time from infection to egg production is 65 to 90 days. [The worms can also reach other organs and tissues, such as the brain and striated muscles, respectively. However, when this takes place the lifecycle can not be completed.

Infections may persist for 20 years in humans.

Animals such as pigs, dogs and a variety of feline species can also harbor the parasite.

See https://www.cdc.gov/parasites/paragonimus/ biology.html for detailed lifecycle.

Figure 13. Paragonimus exposure cycle (Created by Design2 for the GWPP) 


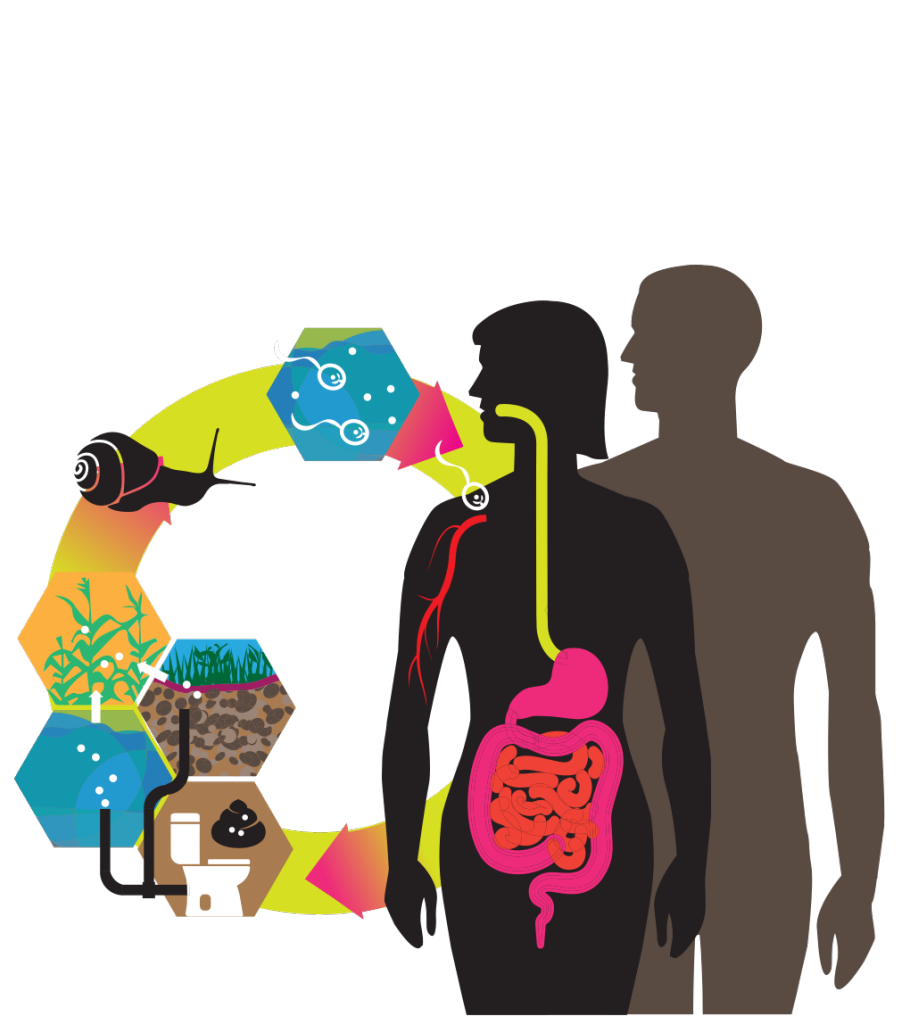

\section{Schistosoma spp.}

Common name: Blood Fluke

Humans are the definitive host as well as other mammals.

Mature and infectious eggs are passed with urine and feces and can end up in sewage and sludge but must make their way to water.

Eggs survive for 7 to 14 days.

Eggs that reach fresh water hatch and release free-living ciliated miracidia. The miracidia which swim can penetrate specific snail hosts (intermediate hosts).

Exposure occurs when humans are in the water where the infective cercariae released from the snail, swim and penetrate the skin of the human host and shed their forked tail, becoming schistosomulae.

Inside the host:The schistosomulae migrate through several tissues to their residence in the veins. The females deposit eggs in the small venules of the portal and perivesical systems. Eggs move progressively toward the lumen of the intestine, bladder and ureters and are eliminated with feces or urine.

Various animals, such as dogs, cats, rodents, pigs, horses and goats, serve as reservoirs.

See https://www.cdc.gov/parasites/schistosomiasis/ biology.thm for the detailed lifecycle.

Figure 14. Schistosoma exposure cycle (Created by Design2 for the GWPP)

\subsubsection{Latency in the environment and/or intermediate hosts}

After excretion, some pathogens (latent pathogens) require time to undergo further development in the environment before they become infectious. Latency is the period of time between the excretion of the pathogen and the time that it is infective to a new susceptible host. Most fecal-oral pathogens, including all bacteria, enteric viruses, and protozoa have no latent period, and thus they are immediately infectious and only have definitive hosts after excretion from an infected individual (see Table 8). Other protists such as Cyclospora cayetanensis and Toxoplasma gondii are also latent. 
Table 8. Latency and zoonotic features of waterborne and excreta associated pathogens

Adenoviruses

Astrovirus

Hepatitis A and E Viruses

Norovirus and other Caliciviruses

Polioviruses and other Enteroviruses

Rotavirus

Non-latent: Immediately Infectious upon excretion in the feces spread via the fecal-oral route

Viruses

Non-latent: The waterborne transmission route has not been fully defined.

\section{Papillomavirus}

Polyomavirus

None

None

None

Latent: Oocyts and eggs are excreted in human feces but are NOT immediately infectious, requires time in the environment depending on the environmental conditions (optimum: moist, warm, shaded soil) prior to maturing to an infective stage. (Range of days prior to becoming infectious)

None are latent

None are latent

\section{Cyclospora cayetanensis \\ (7 to 15 days) \\ Toxoplasma \\ gondii (spread not from human feces but from} cat feces)

(1 to 5 days)
No intermediate host (Soiltransmitted nematodes) Ascaris spp. (18 to 21 days) Hookworms: Ancylostoma duodenale, Necator americanus

(Larvae hatch in 1 to 2 days, become infective larvae after 5 to 10 days) Trichuris trichiura

(15 to 30 days)

Zoonotic: Pathogens can be spread from animals to humans (and in some cases humans to animals)

Hepatitis E virus
Arcobacter butzieri

Campylobacter jejuni and

Campylobacter coli

Leptospira (Rodent-vector

excreted in the urine)

Non-typhoid Salmonella enterica

Pathogenic members of

Escherichia coli

Yersinia spp.

\section{Balantidium coli Blastocystis hominis Taenia spp.}

Cryptosporidium Echinococcus spp spp. Toxocara spp. Giardia duodenalis Toxoplasma gondii 
All excreted helminths require a distinct latency in the environment, either (i) because their eggs must develop into an infectious stage outside the hosts (e.g. soiltransmitted nematodes) or (ii) because some helminths must transmit through one or more intermediate hosts to complete their life cycles as described in the section 4.1.1. Understanding the pathogen latency is critical for controlling their spread and planning of effective prevention measures for a variety of water-related diseases. For example, excreted helminths infections with intermediate hosts can be controlled by preventing excreta from reaching intermediate hosts or avoiding consumption of uncooked intermediate hosts.

\subsubsection{Persistence in the environment}

The ability of a pathogen to be transmitted by water routes depends largely on its persistence in the environment. The longer a pathogen can persist, a greater likelihood of the pathogen to come into contact with a susceptible host, and thus increases the probability of waterborne transmission. Once microorganisms are released into the environment, they are dispersed into water or soil. Since microorganisms have an intrinsic electrostatic charge, they tend to attach to the surface of charged particles in the environment, enhancing their persistence (Hurst, 2007).

Pathogen survival time in the environment depends on environmental conditions both physical and chemical such as temperature, sunlight, dissolved oxygen, dissolved organic carbon, availability of nutrients and salinity.
Pathogens may also be subjected to biochemical antagonism by microbial products such as enzymes, and to predation by other environmental microorganisms. In general, viruses and protozoan cysts and oocysts survive longer in the environment than vegetative bacteria (see Part Four. Persistence of Pathogens in Sewage and Other Water Types). The survival of the pathogen in various water and wastewater treatment processes is also essential in understanding the risk of water-related transmission (see Part Four. Sanitation System Technologies). Temperature has been identified as the important environmental condition influencing bacteria and virus persistence in wastewater (Figure 15). Figure 15 (a) shows greater bacteria inactivation in wastewaters at high temperatures, with approximately 30 and 10 days are needed for a $1 \log 10$ reduction under dark condition at low temperatures and at ambient temperatures, respectively. In wastewater sludge with higher solids, the data suggests that 75 to 100 days are needed for a $1 \log 10$ bacteria reduction at ambient temperatures. Figure 14 (b) shows clear virus inactivation dependency based on temperature and virus type in primary and secondary effluent. Noroviruses are highly persistent in wastewaters, with approximately 115 and 20 days are needed for $1 \log 10$ norovirus inactivation under dark condition at low temperatures and at ambient temperatures, respectively. For adenovirus and poliovirus, approximately 60 and 10 days are needed for a $2 \log 10$ reduction under dark condition at low temperatures and at ambient temperatures, respectively. Adenoviruses are also susceptible to UV radiation at both low and high temperatures. 


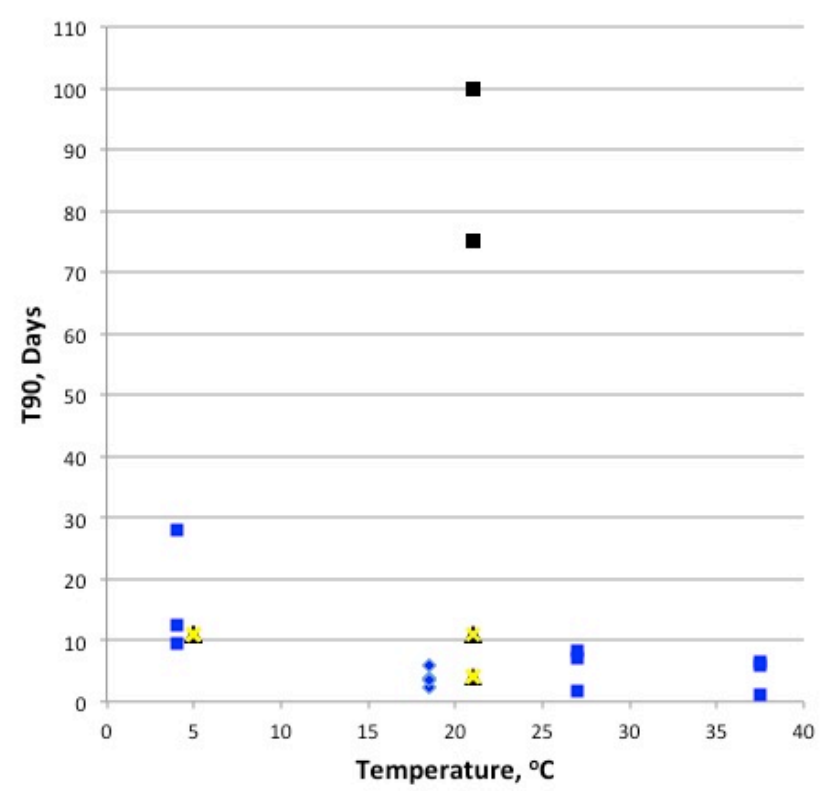

- Bacteria: Waswater sludge, light source: not reported (T90 days)

A Bacteria: Raw Wastewater, light source: dark (T90 days)

- Bacteria: 1:18\% dilution wastewater into sewater or freshwater, light source: dark (T90 days)

- Bacteria: $10 \%$ sewage by volume into river water, light source: dark (T90 days)

Bacteria: Secondary effluent, light source: dark (T90 days)

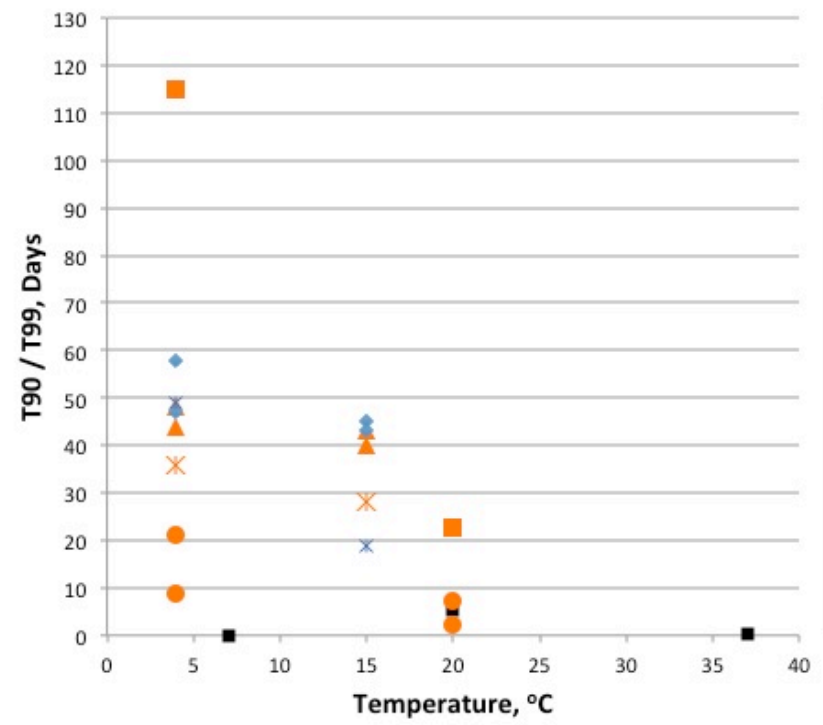

- Adenovirus: Raw wastewater, under UV radiation (T99 days)

- Bacteriophage: Primary effluent, light source: dark (T90 days)

Norovirus: Primary effluent, light source: dark (T90 days)

Adenovirus: Primary effluent, light source: dark (T99 days)

X Poliovirus: Primary effluent, light source: dark (T99 days)

Adenovirus: Secondary effluent, light source: dark (T99 days)

x Poliovirus: Secondary effluent, light source: dark (T99 days)

Figure 15. The persistence of (a) bacteria and (b) viruses in raw sewage, primary effluent and secondary effluent under different temperatures conditions. The T90 and T99 data represent the time in days that it takes for a $1 \log 10$ and $2 \log 10$ reduction of the microorganism to be observed.

Data source: Part Four. Management of Risk from Excreta and Wastewater. Persistence of Pathogens in Sewage and Other Water Types.

Some pathogenic bacteria such as Salmonella, Campylobacter, Helicobacter pylori and Vibrio cholerae are capable of entering a dormant state which known as "viable but non-culturable" and allows them to survive longer under unfavorable environmental conditions and yet maintain their pathogenicity (Ramamurthy et al., 2014). Some of the important properties of viruses that allow some enteric viruses to survive sewage treatment processes and persist in the environment include their smaller size, stability over a wide range of temperature and $\mathrm{pH}$, resistance to various chemical agents such as oxidants and proteolytic enzymes and tendency to aggregate and adsorb to particles and surfaces.

\subsubsection{Dose-response}

The dose response is the relationship between the pathogen and host and provides an assessment of a pathogen estimate of potency (or the infectiousness) specific to that particular pathogen (see Part I: Risk Assessment for Sanitation). Infectious dose is often a term used but it must be used in context of the understanding the dose-response relationship between the pathogen and it's host. This includes a type of response in human (e.g. infection, illness or death) or the probability of an adverse health effect occurs at some ratio to those exposed to a given known dose of a pathogen. Dose- response models are mathematical functions that describe the dose experiments for a specific pathogen, transmission routes and hosts. These models allow for one to produce the infectious dose at varying levels. This number is estimation 
based on clinical experiments and gives an indication of how easily an infection can occur. The dose that induces infection in $50 \%$ of exposed individuals, described as the median infectious dose (ID50), varies greatly among environmentally transmitted pathogens. In general, viruses and protozoa have a lower ID50 than the bacteria, which means that they have a high probability of causing infection when ingested at a very low dose (as few as one ingested pathogen) (Table 9). Helminths are assumed to have high potency too because every larva or egg of a helminth has a potential to become an adult worm but dose-response data for helminths are not available.

Table 9. Key pathogens with infectious dose $\left(\mathrm{ID}_{50}{ }^{\mathrm{a}}\right)$

\begin{tabular}{|c|c|c|c|}
\hline Pathogen & $\mathbf{I D}_{50}$ & Dose Unit & Reference \\
\hline \multicolumn{4}{|c|}{ Viruses } \\
\hline Adenovirus, type 4 & 1.14 & $\mathrm{TCID}_{50}$ & Couch et al., 1966 \\
\hline Echovirus, strain 12 & $9.22 \mathrm{E}+02$ & PFU & Schiff et al., 1984 \\
\hline Enteroviruses & $1.85 \mathrm{E}+02$ & PFU & Cliver, 1981 \\
\hline Poliovirus, type 1 & 1.41 & $\mathrm{PD}_{50}$ & Koprowski, 1956 \\
\hline Rotavirus & 6.17 & FFU & Ward et al.,1986 \\
\hline \multicolumn{4}{|c|}{ Bacteria } \\
\hline Escherichia coli enterohemorrhagic (EHEC) & $3.18 \mathrm{E}+03$ & $\mathrm{CFU}$ & Cornick and Helgerson, 2004 \\
\hline $\begin{array}{l}\text { Campylobacter jejuni and Campylobacter } \\
\text { coli }\end{array}$ & $8.90 \mathrm{E}+02$ & $\mathrm{CFU}$ & Black et al., 1988 \\
\hline Salmonella typhi & $1.11 \mathrm{E}+06$ & $\mathrm{CFU}$ & $\begin{array}{c}\text { Hornick et al., 1966; Hornick et al., } \\
1970\end{array}$ \\
\hline Shigella & $1.48 \mathrm{E}+03$ & $\mathrm{CFU}$ & DuPont et al., 1972 \\
\hline Vibrio cholera & $2.43 \mathrm{E}+02$ & $\mathrm{CFU}$ & Hornick et al., 1971 \\
\hline Yersinia pestis & $4.26 \mathrm{E}+02$ & CFU & Lathem et al., 2005 \\
\hline \multicolumn{4}{|c|}{ Protists } \\
\hline $\begin{array}{l}\text { Cryptosporidium parvum and } \\
\text { Cryptosporidium hominis }\end{array}$ & $1.21 \mathrm{E}+01$ & Oocysts & Messner et al., 2001 \\
\hline Giardia duodenalis & $3.48 \mathrm{E}+1$ & Cysts & Rendtorff, 1954 \\
\hline
\end{tabular}

Source: QMRAwiki, http://qmrawiki.canr.msu.edu/index.php/Dose_Response

${ }^{\mathrm{a}} \mathrm{ID}_{50}$ : Dose that infects $50 \%$ of those exposed.

\subsection{Environmental Factors}

4.2.1 The source of the pathogens and reservoirs of infection (Zoonosis)

For some pathogens the main reservoir and source of human infection is restricted to human hosts, this includes for example, shigellosis and many viral infections which are confined strictly to humans, and thus the control of human excreta alone is required to interrupt the transmission pathway. However, many other diseases (for example, salmonellosis, cryptosporidiosis, giardiasis and many of the helminth infections) involve wild or domestic vertebrate animals as well as humans. Such an infections are termed zoonoses and the pathogens involved are referred to as zoonotic pathogens. Approximately $60 \%$ of the emerging infectious diseases are zoonoses by analysis of a database of 335 emerging infectious disease events between 1940 and 2004 globally (Jones et al., 2008). Examples of important zoonotic pathogens include pathogenic members of E. coli, Salmonella, Campylobacter, Yersinia, hepatitis E virus and protozoan parasites Cryptosporidium, Giardia and Toxoplasma gondii (Table 8). Susceptible populations in rural regions with high animal densities and in developing countries where water treatment and proper waste management is inadequate often face the highest risk of infections with waterborne zoonotic pathogens (Dreelin et al., 2014; Khan et al., 2010).

Among the helminths, Taenia saginata (beef measles worm) and Taenia solium (pork measles worm) are zoonotic pathogens for which transmission to humans is primarily through the ingestion of contaminated under-cooked beef or pork. Other helminths include Echinococcus, Toxocara, and Fasciola, which multiple host susceptibility is being recognized, and thus enhancing the likelihood of zoonotic transmission (Robinson and Dalton, 2009).

There are three broad criteria for zoonotic waterrelated disease (Moe, 2004): (i) In order for zoonotic pathogens to present a disease risk to human, they must 
first establish part of their life cycle within one or more animal species and subsequently be able to multiply and develop within a human host as well; (ii) Within the life cycle of the zoonotic pathogen, they must be transported from animal excreta to surface or ground water and persist in water in order to be transmitted by the water exposure; and (iii) the pathogen must be transmitted from animal source to human through a water-related route such as ingestion, water contact and consumption of seafood infected with the pathogen or harvested from water impacted by animal waste.

\subsubsection{The exerted load released into the environment}

The load of pathogens entering the environment depends on the prevalence of the infection in the human and animal populations, the concentration of the pathogen in the waste (feces or urine) of infected populations as well as the intensity and duration of pathogen shedding by an infected individual. For example, the prevalence of gastrointestinal illnesses shows region-specific distribution with developing regions have significantly more pathogens isolated than the developed regions (Fletcher et al., 2013a) and this may result in increased loads of pathogens that may be released into the environment. In addition, there is a strong relationship between infections with enteric viruses and seasons in temperate climate regions with rotavirus and norovirus infections often peak in the cooler months (Ahmed et al., 2013; Fletcher et al., 2013b). The prevalence of zoonotic pathogens such as Cryptosporidium and Giardia can be influenced by the reproductive cycles of their host cattle and thus calving season may result in higher infection rates and increased loads of oocysts and cysts that may be released into the environment (NRC, 2004). Sewage discharges, type of treatment and the volume of receiving waters can greatly influence local loads and concentrations of pathogens in the water environment (Medema and Schijven, 2001).

Pathogen concentrations in human feces can be very high, typically at concentrations of millions to billions of organisms per gram of feces, and even higher for some viral pathogens such as rotavirus (Table 10). After releasing into the environment, the pathogen concentrations generally decrease due to dilution and dispersion in environmental media and inactivation or die-off influencing by several environmental conditions as discussed in the section 4.1.3. However, fecal waste in the environment, particularly excreta in latrines in developing regions and untreated raw sewage (Table 10) can still contain high concentrations of pathogens and can be sources of exposure if human come in contact with them (Sobsey, 2015).

Table 10. Pathogen concentrations in feces and raw sewage

\begin{tabular}{|c|c|c|c|c|}
\hline Pathogen & $\begin{array}{c}\text { Concentration Per g } \\
\text { in Feces }\end{array}$ & $\begin{array}{c}\text { Concentration Per Liter } \\
\text { in Raw Sewage } \\
\end{array}$ & $\begin{array}{c}\text { Notes Regarding Sewage } \\
\text { Data }\end{array}$ & References \\
\hline \multicolumn{5}{|c|}{ Viruses } \\
\hline Adenoviruses & $1 \mathrm{E}+11$ particles & $\begin{array}{l}1.7 \mathrm{E}+02 \text { to } \\
3.3 \mathrm{E}+09 \mathrm{GC}^{\mathrm{a}}\end{array}$ & $\begin{array}{c}\text { Based on } 8 \text { studies in Brazil, } \\
\text { Europe, Japan, USA and New } \\
\text { Zealand. }\end{array}$ & $\begin{array}{c}\text { Allard and } \\
\text { Vantarakis, } 2017\end{array}$ \\
\hline Hepatitis A virus & $>1 \mathrm{E}+06$ particles & $\begin{array}{l}2.95 \mathrm{E}+05 \\
\text { to } 9.8 \mathrm{E}+08 \mathrm{GC}\end{array}$ & $\begin{array}{c}\text { Based on } 5 \text { studies in Brazil and } \\
\text { Tunisia. }\end{array}$ & $\begin{array}{l}\text { van der Poel and } \\
\text { Rzezutka, 2017a }\end{array}$ \\
\hline Hepatitis E virus & $1 \mathrm{E}+05 \mathrm{GC}$ & $1 \mathrm{E}+04 \mathrm{GC}$ & $\begin{array}{l}\text { Based on } 2 \text { studies in Norway } \\
\text { and Switzerland. }\end{array}$ & $\begin{array}{l}\text { van der Poel and } \\
\text { Rzezutka, 2017b }\end{array}$ \\
\hline $\begin{array}{l}\text { Norovirus and } \\
\text { other } \\
\text { caliciviruses }\end{array}$ & $1 \mathrm{E}+11 \mathrm{GC}$ & $\begin{array}{l}1.7 \mathrm{E}+02 \text { to } \\
3.4 \mathrm{E}+09 \mathrm{GC}\end{array}$ & $\begin{array}{c}\text { Based on } 18 \text { studies in Europe, } \\
\text { Japan, Uruguay, New Zealand } \\
\text { and USA. }\end{array}$ & $\begin{array}{l}\text { Katayama and } \\
\text { Vinjé, } 2017\end{array}$ \\
\hline $\begin{array}{l}\text { Polioviruses and } \\
\text { other } \\
\text { Enteroviruses }\end{array}$ & $1 \mathrm{E}+06$ to $1 \mathrm{E}+07$ & $\begin{array}{c}0 \text { to } 3.4 \mathrm{E}+04 \text { (cell } \\
\text { culture) } \\
2.4 \mathrm{E}+02 \text { to } \\
4.7 \mathrm{E}+06 \mathrm{GC}\end{array}$ & $\begin{array}{c}\text { Based on } 15 \text { studies in Africa, } \\
\text { Europe, Japan, New Zealand } \\
\text { and USA. }\end{array}$ & $\begin{array}{l}\text { Betancourt and } \\
\text { Shulman, } 2016\end{array}$ \\
\hline Polyomavirus & No quantitative data & $\begin{array}{l}1.5 \mathrm{E}+04 \text { to } \\
1 \mathrm{E}+08 \mathrm{GC}\end{array}$ & $\begin{array}{l}\text { Based on } 9 \text { studies in Brazil, } \\
\text { Europe, New Zealand and USA. }\end{array}$ & Bofill-Mas, 2016 \\
\hline Rotavirus & $\begin{array}{c}1 \mathrm{E}+10 \text { to } \\
1 \mathrm{E}+12 \text { particles }\end{array}$ & $\begin{array}{l}2.2 \mathrm{E}+02 \text { to } \\
2.9 \mathrm{E}+08 \mathrm{GC}\end{array}$ & $\begin{array}{c}\text { Based on } 5 \text { studies in Argentina, } \\
\text { Brazil, China and USA. }\end{array}$ & $\begin{array}{l}\text { da Silva et } \\
\text { al., } 2016\end{array}$ \\
\hline Astrovirus & $7.6 \mathrm{E}+02$ to $3.6 \mathrm{E}+15 \mathrm{GC}$ & $\begin{array}{c}1 \mathrm{E}+03 \text { to } \\
4.3 \mathrm{E}+07 \mathrm{GC}\end{array}$ & $\begin{array}{l}\text { Based on } 5 \text { studies in Brazil, } \\
\text { France, Japan, Singapore and } \\
\text { Uruguay. }\end{array}$ & $\begin{array}{l}\text { da Silva et } \\
\text { al., } 2016\end{array}$ \\
\hline \multicolumn{5}{|c|}{ Bacteria } \\
\hline
\end{tabular}




\begin{tabular}{|c|c|c|c|c|}
\hline Pathogen & $\begin{array}{c}\text { Concentration Per g } \\
\text { in Feces } \\
\end{array}$ & $\begin{array}{c}\text { Concentration Per Liter } \\
\text { in Raw Sewage } \\
\end{array}$ & $\begin{array}{c}\text { Notes Regarding Sewage } \\
\text { Data }\end{array}$ & References \\
\hline Arcobacter & $<100 \mathrm{CFU}^{\mathrm{b}}$ & $1 \mathrm{E}+06$ to $2.6 \mathrm{E}+08 \mathrm{MPN}^{\mathrm{c}}$ & $\begin{array}{l}\text { Based on } 2 \text { studies in Australia } \\
\text { and Canada. }\end{array}$ & $\begin{array}{l}\text { Banting and } \\
\text { Figueras Salvat, } \\
2017\end{array}$ \\
\hline Campylobacter & $6 \mathrm{E}+06$ to $1 \mathrm{E}+09 \mathrm{CFU}$ & $\begin{array}{c}1 \mathrm{E}+02 \text { to } 1 \mathrm{E}+07 \mathrm{CFU} \\
2.5 \mathrm{E}+03 \text { to } \\
1.6 \mathrm{E}+04 \mathrm{MPN} \\
4.1 \mathrm{E}+06 \mathrm{GC}\end{array}$ & $\begin{array}{l}\text { Based on } 5 \text { studies in Europe } \\
\text { and USA. }\end{array}$ & $\begin{array}{l}\text { Pitkanen and } \\
\text { Hanninen, } 2017\end{array}$ \\
\hline $\begin{array}{l}\text { Pathogenic } \\
\text { member of E. } \\
\text { coli and Shigella } \\
\text { spp. }\end{array}$ & $\begin{array}{c}1 \mathrm{E}+06 \text { to } 1 \mathrm{E}+08 \mathrm{CFU} \\
\quad \text { (Shigella) } \\
1 \mathrm{E}+02 \text { to } 1 \mathrm{E}+05 \mathrm{CFU} \\
\text { (Pathogenic } \mathrm{E} . \text { coli in } \\
\quad \text { cattle feces) }\end{array}$ & $\begin{array}{c}1.5 \mathrm{E}+03 \text { to } 1.4 \mathrm{E}+07 \mathrm{CFU} \\
\text { (Shigella) } \\
\mathrm{E}+02 \text { to E+04 CFU } \\
\text { (Pathogenic E. coli) }\end{array}$ & $\begin{array}{l}\text { Based on } 2 \text { studies in South } \\
\text { Africa and Spain. }\end{array}$ & $\begin{array}{l}\text { Garcia-Aljaro et } \\
\text { al., } 2017\end{array}$ \\
\hline $\begin{array}{l}\text { Helicobacter } \\
\text { pylori }\end{array}$ & No quantitative data & $2 \mathrm{E}+03$ to $2.8 \mathrm{E}+04 \mathrm{GC}$ & Based on one study in USA. & $\begin{array}{l}\text { Araujo Boira and } \\
\text { Hanninen, } 2017\end{array}$ \\
\hline \multicolumn{5}{|c|}{ Protists } \\
\hline Balantidium coli & No Data & 5 to $7.5 \mathrm{E}+04$ cysts & $\begin{array}{l}\text { Based on one study in } \\
\text { Bangladesh. }\end{array}$ & $\begin{array}{l}\text { Ponce-Gordo and } \\
\text { Jirku-Pomajbíková, } \\
2017\end{array}$ \\
\hline Blastocystis & $7.4 \mathrm{E}+05$ cysts & $\begin{array}{l}\text { Cysts were detected in } \\
\text { raw sewage but no } \\
\text { quantitative data } \\
\text { available. }\end{array}$ & $\begin{array}{c}\text { Based on } 3 \text { studies in Pakistan, } \\
\text { Malaysia, Philippines and } \\
\text { Scotland. }\end{array}$ & $\begin{array}{c}\text { de la Cruz and } \\
\text { Stensvold, } 2017\end{array}$ \\
\hline $\begin{array}{l}\text { Cyclospora } \\
\text { cayetanensis }\end{array}$ & $1 \mathrm{E}+02$ to $1 \mathrm{E}+04$ oocysts & $1.2 \mathrm{E}+04 \mathrm{GC}$ & Based on a study in USA. & $\begin{array}{l}\text { Chacin-Bonilla, } \\
2017\end{array}$ \\
\hline $\begin{array}{l}\text { Cryptosporidium } \\
\text { spp. }\end{array}$ & $\begin{array}{c}1 \mathrm{E}+05 \text { to } \\
1 \mathrm{E}+07 \text { oocysts }\end{array}$ & 1 to $6 \mathrm{E}+04$ oocysts & $\begin{array}{c}\text { Based on } 20 \text { studies in South } \\
\text { and North America, Asia, } \\
\text { Europe and Africa. }\end{array}$ & Nasser, 2016 \\
\hline Entamoeba coli & 1256 cysts & 1329 to 2834 cysts & 17 wastewater treatment plants & $\begin{array}{l}\text { Ben Ayed and } \\
\text { Sabbahi, }\end{array}$ \\
\hline $\begin{array}{l}\text { Entamoeba } \\
\text { histolytica }\end{array}$ & 854 cysts & 893 cysts & in Tunisia & $\begin{array}{l}\text { 2017; Sossou et } \\
\text { al., } 2014\end{array}$ \\
\hline Microsporidia & $\begin{array}{c}2.4 \mathrm{E}+02 \text { to } \\
1.2 \mathrm{E}+05 \text { spores }\end{array}$ & $\begin{array}{l}51 \text { to } 1000 \text { spores } \\
\text { (sewage sludge) }\end{array}$ & Based on 2 studies in Ireland. & Feng and Li, 2017 \\
\hline $\begin{array}{l}\text { Toxoplasma } \\
\text { gondii }\end{array}$ & $1 \mathrm{E}+06$ oocysts & $\begin{array}{c}\text { Toxoplasma were } \\
\text { detected in raw sewage } \\
\text { but no quantitative data } \\
\text { available. }\end{array}$ & $\begin{array}{c}\text { Based on } 3 \text { studies in Europe } \\
\text { and Japan. }\end{array}$ & $\begin{array}{l}\text { Bahia-Oliveira et } \\
\text { al., } 2017\end{array}$ \\
\hline $\begin{array}{l}\text { Giardia } \\
\text { duodenalis }\end{array}$ & 56 to $5 E+06$ cysts & $\begin{array}{l}759 \text { cysts } \\
1 \text { to } 1 \mathrm{E}+05 \text { cysts }\end{array}$ & $\begin{array}{c}17 \text { wastewater treatment plants } \\
\text { in Tunisia. } \\
\text { Based on } 17 \text { studies in Asia, } \\
\text { North and South America, } \\
\text { Europe and South Africa. }\end{array}$ & $\begin{array}{l}\text { Boarato-David et } \\
\text { al., } 2016\end{array}$ \\
\hline \multicolumn{5}{|c|}{ Helminths } \\
\hline Ascaris spp. & 204 eggs & $\begin{array}{l}46 \text { eggs (Maximum: 175) } \\
455 \text { eggs }\end{array}$ & $\begin{array}{c}\text { Based on a study in Iran }(\mathrm{N}= \\
60) \\
17 \text { wastewater treatment plants } \\
\text { in Tunisia }\end{array}$ & $\begin{array}{l}\text { Sossou et al., } \\
\text { 2014; Sharafi et } \\
\text { al., } 2015\end{array}$ \\
\hline $\begin{array}{l}\text { The Liver } \\
\text { Flukes: } \\
\text { Clonorchis } \\
\text { sinensis, } \\
\text { Opisthorchis } \\
\text { spp, and } \\
\text { Metorchis spp. }\end{array}$ & $2.8 \mathrm{E}+03$ eggs & No data & No Data & $\begin{array}{l}\text { Murell and Pozio, } \\
2017\end{array}$ \\
\hline $\begin{array}{l}\text { Echinococcus } \\
\text { spp. }\end{array}$ & 300 to 600 eggs & No data & No Data & $\begin{array}{l}\text { Vuitton et al., } \\
2017\end{array}$ \\
\hline Taenia spp. & No data & 51 eggs & $\begin{array}{c}17 \text { wastewater treatment plants } \\
\text { in Tunisia }\end{array}$ & $\begin{array}{l}\text { Ben Ayed et al., } \\
2009\end{array}$ \\
\hline
\end{tabular}




\begin{tabular}{lcccc}
\hline \multicolumn{1}{c}{ Pathogen } & $\begin{array}{c}\text { Concentration Per g } \\
\text { in Feces }\end{array}$ & $\begin{array}{c}\text { Concentration Per Liter } \\
\text { in Raw Sewage }\end{array}$ & $\begin{array}{c}\text { Notes Regarding Sewage } \\
\text { Data }\end{array}$ & References \\
\cline { 2 - 4 } $\begin{array}{l}\text { Schistosoma } \\
\text { mansoni }\end{array}$ & 53 eggs & No data & No Data & Sossou et al., \\
$\begin{array}{l}\text { Trichuris } \\
\text { trichiura }\end{array}$ & 117 eggs & No data & No Data & Sossou et al., \\
2014
\end{tabular}

${ }^{\mathrm{a}} \mathrm{GC}$ : Gene copies; ${ }^{\mathrm{b}} \mathrm{CFU}$ : Colony forming unit; ${ }^{\mathrm{c}} \mathrm{MPN}$ : Most probable number

\subsubsection{Vectors}

The transmission of pathogens from one host to another may involve intermediate hosts or vectors. Vectors are living organisms such as mosquitoes, ticks, flies, freshwater snails and rodents that can transmit infectious diseases between humans or from animals to humans (WHO, 2014). These are of primary importance for the protists and helminths.

Freshwater snails play an important role as vectors in several trematode helminths including the liver flukes: Clonorchis sinensis, Opisthorchis spp., and Metorchis spp. and Fasciolopsis buski, intestinal flukes: Heterophyidae and Echinostomatidae, Paragonimus spp., and Schistosoma spp. causing schistosomiasis (see Part Three. Section IV. Helminths) and other water-related parasitic diseases caused by helminths (Table 7). These parasites grow in certain types of freshwater snails and the infectious form of the parasite, known as cercariae, emerge from the snail and contaminate water. Human can become infected when skin comes into contact with contaminated freshwater.

Rodents are also considered a major reservoir of zoonotic and vector-borne diseases such as Leptospirosis (see Part Three. Section II. Leptospiria and Leptospirosis). Leptospirosis has been linked to unplanned urbanization, particularly urban slums with the lack of improved sanitation, overcrowding that favor rodent populations (Costa et al., 2017). 


\section{References}

Ahmed, SM, Hall, AJ, Robinson, AE, Verhoef, L, Premkumar, P, Parashar, UD et al. (2014). Global prevalence of norovirus in cases of gastroenteritis: a systematic review and meta-analysis. The Lancet infectious diseases. 14, pp. 725-730.

Ahmed, SM, Lopman, BA and Levy, K (2013). A Systematic Review and Meta-Analysis of the Global Seasonality of Norovirus. PLOS ONE. 8, pp. e75922. doi: 10.1371/journal.pone.0075922.

Allard, A. and Vantarakis, A. (2017). Adenoviruses. Global Water Pathogens Project. http://www.waterpathogens.org . (Jiménez-Cisneros, J.B.Rose and., B, ed.).

Aw, TGim and Rose, JB (2012). Detection of pathogens in water: from phylochips to qPCR to pyrosequencing. Current Opinion in Biotechnology. 23, pp. 422-430. doi: 10.1016/j.copbio.2011.11.016.

Bahia-Oliveira, L., Gomez-Marin, J. and Shapiro, K. (2017). Toxoplasma gondii . Global Water Pathogens Project. http://www.waterpathogens.org. (Jiménez-Cisneros, J.B.Rose and., B, ed.).

Bain, R, Cronk, R, Wright, J, Yang, H, Slaymaker, T and Bartram, J (2014). Fecal contamination of drinking-water in lowand middle-income countries: a systematic review and meta-analysis. PLoS medicine. 11, pp. e1001644.

Banting, G. and Salvat, M.J.Figueras (2017). Arcobacter. Global Water Pathogens Project. http://www.waterpathogens.org. (Jiménez-Cisneros, J.B.Rose and., B, ed.).

Barzilay, EJ, Schaad, N, Magloire, R, Mung, KS, Boncy, J, Dahourou, GA et al. (2013). Cholera surveillance during the Haiti epidemic-the first 2 years. New England Journal of Medicine. 368, pp. 599-609.

Ben Ayed, L. and Sabbahi, S. (2017). Entamoeba histolytica . Global Water Pathogens Project. http://www.waterpathogens.org . (Jiménez-Cisneros, J.B.Rose and., B, ed.).

Ben Ayed, L., Schijven, J., Alouini, Z., Jemli, M. and Sabbahi, S. (2009). Presence of parasitic protozoa and helminth in sewage and efficiency of sewage treatment in Tunisia. Parasitology Research. 105, pp. 393. doi: 10.1007/s00436-009-1396y.

Betancourt, W.Q. and Shulman, L.M (2016). Polioviruses and other Enteroviruses. Global Water Pathogens Project. http://www.waterpathogens.org . (Jiménez-Cisneros, J.B.Rose and., B, ed.).

Black, R.E, Levine, M.M, Clements, M.L, Hughes, T.P and Blaser, M.J (1988). Experimental Campylobacter jejuni infection in humans. J Infect Dis. 157, pp. 472-9.

Boarato-David, E., Guimarães, S. and Cacciò, S. (2016). Giardia duodenalis. Global Water Pathogens Project. http://www.waterpathogens.org . (Jiménez-Cisneros, J.B.Rose and., B, ed.).

Bofill-Mas, S. (2016). Polyomavirus. Global Water Pathogens Project. http://www.waterpathogens.org . (Jiménez-Cisneros, J.B.Rose and., B, ed.).

R. Boira, A and Hanninen, M.L. (2017). Helicobacter pylori . Global Water Pathogens Project. http://www.waterpathogens.org . (Jiménez-Cisneros, J.B.Rose and., B, ed.).

Bok, K and Green, KY (2012). Norovirus Gastroenteritis in Immunocompromised Patients. New England Journal of Medicine. 367, pp. 2126-2132. doi: 10.1056/NEJMra1207742.

Brown, J, Cairncross, S and Ensink, JHJ (2013). Water, sanitation, hygiene and enteric infections in children. Archives of Disease in Childhood. 98, pp. 629-634. doi: 10.1136/archdischild-2011-301528.

Carr, R (2001). Excreta-related infections and the role of sanitation in the control of transmission. World Health Organization (WHO). Water Quality: Guidelines, Standards and Health. (Fewtrell, L and Bartram, J, ed.).London, UK CDC (2018). Parasites - Ascariasis. 2018, Atlanta, Georgia 
CDC (2018). DPDx - Laboratory Identification of Parasites of Public Health Concern. 2018, Atlanta, Georgia

CDC (2017). DPDx - Laboratory Identification of Parasites of Public Health Concern. 2018, Atlanta, Georgia

CDC (2016). DPDx - Laboratory Identification of Parasitic Diseases of Public Health Concern. 2017, Atlanta, Georgia

CDC (2015). Parasites - Paragonimiasis. 2018, Atlanta, Georgia

CDC (2014). Cholera - Vibrio cholerae infection. Non-O1 and Non-O139 Vibrio cholerae ifecetions.

CDC (2013). Parasites - Taeniasis. 2018, Atlanta, Georgia

CDC (2013). Parasites - Toxocariasis (also known as Roundworm Infection). 2018, Atlanta, Georgia

CDC (2013). Parasites - Trichuriasis (also known as Whipworm Infection). 2018, Atlanta, Georgia

CDC (2013). Parasites - Hookworm. 2018, Atlanta, Georgia

CDC (2013). Parasites Fasciola. 2018, Atlanta, Georgia

CDC (2012). Parasites - Schistosomiasis. 2018, Atlanta, Georgia

CDC (2012). Diphyllobothrium latum (and other species) FAQs. 2018, Atlanta, Georgia

Chacin-Bonilla, L. (2017). Cyclospora Cayetanensis . Global Water Pathogens Project. http://www.waterpathogens.org . (Jiménez-Cisneros, J.B.Rose and., B, ed.).

Cliver, DO (1981). Experimental Infection by Waterborne Enteroviruses. Journal of Food Protection. 44, pp. 861-865. doi: 10.4315/0362-028x-44.11.861.

Cornick, N.A and Helgerson, A.F (2004). Transmission and Infectious Dose of Escherichia coli O157:H7 in Swine. Applied and Environmental Microbiology. 70, pp. 5331-5335. doi: 10.1128/AEM.70.9.5331-5335.2004.

Costa, F, Carvalho-Pereira, T, Begon, M, Riley, L and Childs, J (2017). Zoonotic and Vector-Borne Diseases in Urban Slums: Opportunities for Intervention. Trends in Parasitology.

Couch, R.B, Cate, T.R, Douglas, R.G, Gerone, P.J and Knight, V. (1966). Effect of route of inoculation on experimental respiratory viral disease in volunteers and evidence for airborne transmission. Bacteriological Reviews. 30, pp. 517-529.

da Silva, M., Miagostovich, M. and Victoria, M. (2016). Rotavirus and Astroviruses. Global Water Pathogens Project. http://www.waterpathogens.org. (Jiménez-Cisneros, J.B.Rose and., B, ed.).

de la Cruz, C. and Stensvold, R. (2017). Blastocystis hominis. Global Water Pathogens Project. http://www.waterpathogens.org . (Jiménez-Cisneros, J.B.Rose and., B, ed.).

Di Comite, G, Dognini, G, Gaiera, G, Ieri, R and Praderio, L (2000). Acute Echinococcosis: a Case Report. Journal of Clinical Microbiology. 38, pp. 4679-4680.

Didier, ES, Stovall, ME, Green, LC, Brindley, PJ, Sestak, K and Didier, PJ (2004). Epidemiology of microsporidiosis: sources and modes of transmission. Veterinary parasitology. 126, pp. 145-166.

Dreelin, EA, Ives, RL, Molloy, S and Rose, JB (2014). Cryptosporidium and Giardia in surface water: a case study from Michigan, USA to inform management of rural water systems. International journal of environmental research and public health. 11, pp. 10480-10503.

DuPont, H.L, Hornick, R.B, Snyder, M.J, Libonati, J.P, Formal, S.B and Gangarosa, E.J (1972). Immunity in shigellosis. I. Response of man to attenuated strains of Shigella. J Infect Dis. 125, pp. 5-11. 
Feng, Y. and Li, N. (2017). Microsporidia. Global Water Pathogens Project. http://www.waterpathogens.org . (JiménezCisneros, J.B.Rose and., B, ed.).

Fletcher, S.M, McLaws, M.L and Ellis, J.T (2013). Prevalence of Gastrointestinal Pathogens In Developed and Developing Countries: Systematic Review and Meta-Analysis. J Public Health Res . 2(1), pp. 42-53.

Fletcher, S., Van Hal, S., Andresen, D., McLaws, M.L, Stark, D., Harkness, J. et al. (2013). Gastrointestinal pathogen distribution in symptomatic children in Sydney, Australia.. J Epidemiol Glob Health. 3(1), pp. 11-21.

Freeman, MC, Clasen, T, Brooker, SJ, Akoko, DO and Rheingans, R (2013). The Impact of a School-Based Hygiene, Water Quality and Sanitation Intervention on Soil-Transmitted Helminth Reinfection: A Cluster-Randomized Trial. The American Journal of Tropical Medicine and Hygiene. 89, pp. 875-883. doi: doi:https://doi.org/10.4269/ajtmh.13-0237.

Garcia-Aljaro, C., Momba, M. and Muniesa, M. (2017). Pathogenic members of Escherichia coli \&amp; Shigella spp. Shigellosis. Global Water Pathogens Project. http://www.waterpathogens.org . (Jiménez-Cisneros, J.B.Rose and., B, ed.).

Gibson, KE (2014). Viral pathogens in water: occurrence, public health impact, and available control strategies. Current opinion in virology. 4, pp. 50-57.

Hornick, R.B, Greisman, S.E, Woodward, T.E, DuPont, H.L, Dawkins, A.T and Snyder, M.J (1970). Typhoid fever: pathogenesis and immunologic control. N Engl J Med. 283, pp. 686-91. doi: 10.1056/nejm197009242831306.

Hornick, R.B, Music, S.I, Wenzel, R., Cash, R., Libonati, J.P, Snyder, M.J et al. (1971). The Broad Street pump revisited: response of volunteers to ingested cholera vibrios. Bull N Y Acad Med. 47, pp. 1181-91.

Hornick, R.B, Woodward, T.E, McCrumb, F.R, Snyder, M.J, Dawkins, A.T, Bulkeley, J.T et al. (1966). Study of induced typhoid fever in man. I. Evaluation of vaccine effectiveness. Trans Assoc Am Physicians. 79, pp. 361-7.

Hulo, C, De Castro, E, Masson, P, Bougueleret, L, Bairoch, A, Xenarios, I et al. (2010). ViralZone: a knowledge resource to understand virus diversity. Nucleic acids research. 39, pp. D576-D582.

Hunter, PR and Nichols, G (2002). Epidemiology and Clinical Features of Cryptosporidium Infection in Immunocompromised Patients. Clinical Microbiology Reviews. 15, pp. 145-154. doi: 10.1128/CMR.15.1.145-154.2002.

Hurst, CJ (2007). Modeling the Fate of Microorganisms in Water, Wastewater and Soil. Manual of Environmental Microbiology. (Hurst, CJ, Crawford, RL, Garland, JL, Lipson, DA, Mills, AL and Stetzenbach, LD, ed.).Washington, D.C.

Itta, KChaaithany, Patil, T, Kalal, S, Ghargi, KVittal and Roy, S (2016). Salivirus in children with diarrhoea, western India. International Journal of Infectious Diseases. 52, pp. 14-15.

J. Janda, M and Abbott, SL (2010). The Genus Aeromonas: Taxonomy, Pathogenicity, and Infection. Clinical Microbiology Reviews. 23, pp. 35-73. doi: 10.1128/CMR.00039-09.

Jones, KE, Patel, NG, Levy, MA, Storeygard, A, Balk, D, Gittleman, JL et al. (2008). Global trends in emerging infectious diseases. Nature. 451, pp. 990-993.

Katayama, H. and Vinje, J. (2017). Norovirus and other Calicivirus. Global Water Pathogens Project. http://www.waterpathogens.org . (Jiménez-Cisneros, J.B.Rose and., B, ed.).

Khan, SManzoor, Debnath, C, Pramanik, AKumar, Xiao, L, Nozaki, T and Ganguly, S (2010). Molecular characterization and assessment of zoonotic transmission of Cryptosporidium from dairy cattle in West Bengal, India. Veterinary parasitology. 171, pp. 41-47.

Koprowski, H. (1956). Immunization against poliomyelitis with living attenuated virus. Am J Trop Med Hyg. 5, pp. 440-52.

Kostyla, C, Bain, R, Cronk, R and Bartram, J (2015). Seasonal variation of fecal contamination in drinking water sources in developing countries: A systematic review. Science of The Total Environment. 514, pp. 333-343. 
Kotloff, KL, Nataro, JP, Blackwelder, WC, Nasrin, D, Farag, TH, Panchalingam, S et al. (2013). Burden and aetiology of diarrhoeal disease in infants and young children in developing countries (the Global Enteric Multicenter Study, GEMS): a prospective, case-control study. The Lancet. 382, pp. 209-222.

Kroes, I, Lepp, PW and Relman, DA (1999). Bacterial diversity within the human subgingival crevice. Proceedings of the National Academy of Sciences. 96, pp. 14547-14552.

Lathem, W.W, Crosby, S.D, Miller, V.L and Goldman, W.E (2005). Progression of primary pneumonic plague: a mouse model of infection, pathology, and bacterial transcriptional activity. Proc Natl Acad Sci U S A. 102, pp. 17786-91. doi: 10.1073/pnas.0506840102.

Leclerc, H, Schwartzbrod, L and Dei-Cas, E (2002). Microbial agents associated with waterborne diseases. Critical reviews in microbiology. 28, pp. 371-409.

Levett, PN (2001). Leptospirosis. Clinical Microbiology Reviews. 14, pp. 296-326. doi: 10.1128/CMR.14.2.296-326.2001.

Ligon, G and Bartram, J (2016). Literature review of associations among attributes of reported drinking water disease outbreaks. International journal of environmental research and public health. 13, pp. 527.

Medema, GJ and Schijven, JF (2001). Modelling the sewage discharge and dispersion of Cryptosporidium and Giardia in surface water. Water research. 35, pp. 4307-4316.

Messner, MJ, Chappell, CL and Okhuysen, PC (2001). Risk assessment for Cryptosporidium: a hierarchical Bayesian analysis of human dose response data. Water Res. 35, pp. 3934-40.

Moe, C.L. (2004). What are the criteria for determining whether a disease is zoonotic and water related?. World Health Organization (WHO). Waterborne Zoonoses: Identification, Causes and Control. (Cotruvo, J.A., Dufour, A., Rees, G., Bartram, J., Carr, R., Cliver, D.O. et al., ed.).London, UK

Murell, K.D. and Pozio, E. (2017). The Liver Flukes: Clonorchis sinensis, Opisthorchis spp, and Metorchis spp.. Global Water Pathogens Project. http://www.waterpathogens.org. (Jiménez-Cisneros, J.B.Rose and., B, ed.).

Nasser, AM (2016). Removal of Cryptosporidium by wastewater treatment processes: a review. Journal of Water and Health. 14, pp. 1-13. doi: 10.2166/wh.2015.131.

NIH (2007). Understanding emerging and re-emerging infectious diseases. Bethesda, MD

NRC (2004). Ecology and Evolution of Waterborne Pathogens and Indicator Organisms. Indicators for Waterborne Pathogens. Washington, DC

Pitkanen, T. and Hanninen, M-L. (2017). Members of the family Campylobacteraceae: Campylobacter jejuni , Campylobacter coli. Global Water Pathogens Project. http://www.waterpathogens.org . (Jiménez-Cisneros, J.B.Rose and., B, ed.).

Ponce-Gordo, F. and Jirků-Pomajbíková, K. (2017). Balantidium coli . Global Water Pathogens Project. http://www.waterpathogens.org . (Jiménez-Cisneros, J.B.Rose and., B, ed.).

Prüss-Ustün, A, Bartram, J, Clasen, T, Colford, JM, Cumming, O, Curtis, V et al. (2014). Burden of disease from inadequate water, sanitation and hygiene in low-and middle-income settings: a retrospective analysis of data from 145 countries. Tropical Medicine \&amp; International Health. 19, pp. 894-905.

Ramamurthy, T, Ghosh, A, Pazhani, GP and Shinoda, S (2014). Current perspectives on viable but non-culturable (VBNC) pathogenic bacteria. Frontiers in public health. 2.

Ramees, TPuram, Dhama, K, Karthik, K, Rathore, RSingh, Kumar, A, Saminathan, M et al. (2017). Arcobacter: an emerging food-borne zoonotic pathogen, its public health concerns and advances in diagnosis and control-a comprehensive review. Veterinary Quarterly. 37, pp. 136-161. 
Rendtorff, R.C (1954). The experimental transmission of human intestinal protozoan parasites. II. Giardia lamblia cysts given in capsules. Am J Hyg. 59, pp. 209-20.

Reuter, G, Pankovics, P and Boros, Á (2016). Saliviruses-the first knowledge about a newly discovered human picornavirus. Reviews in medical virology.

Robinson, MW and Dalton, JP (2009). Zoonotic helminth infections with particular emphasis on fasciolosis and other trematodiases. Philosophical Transactions of the Royal Society of London B: Biological Sciences. 364, pp. 2763-2776.

Schiff, G.M, Stefanovic, G.M, Young, E.C, Sander, D.S, Pennekamp, J.K and Ward, R.L (1984). Studies of echovirus-12 in volunteers: determination of minimal infectious dose and the effect of previous infection on infectious dose. J Infect Dis. 150, pp. 858-66.

Sharafi, K., Pirsaheb, M., Fazlzadeh, M. and Derayat, J. (2015). Comparison of Parasitic Contamination in a Society Based on Measurement of the Domestic Raw Wastewater Pollution and Clinical Referrals. Research Journal of Environmental Sciences. 9, pp. 200-205.

Sobsey, MD (2015). Waterborne and Water-washed Disease. Routledge Handbook of Water and Health. (Bartram, J, Baum, R, Coclanis, PA, Gute, DM, Kay, D, McFadyen, S et al., ed.).London and New York

Sossou, S.K., Sou/Dakoure, M., Hijikata, N., Quenum, A., A.H., M and Funamizu, N. (2014). Removal and Deactivation of Intestinal Parasites in Aerobic Mesophilic Composting Reactor for Urine Diverting Composting Toilet. Compost Science \&amp; Utilization. 22, pp. 242-252.

Tan, BF, Ng, C, Nshimyimana, JPierre, Loh, LLeng, Gin, KY-H and Thompson, JR (2015). Next-generation sequencing (NGS) for assessment of microbial water quality: current progress, challenges, and future opportunities. Frontiers in microbiology. 6.

van der Poel, W. and Rzezutka, A. (2017). Hepatitis A. Global Water Pathogens Project. http://www.waterpathogens.org. (Jiménez-Cisneros, J.B.Rose and., B, ed.).

van der Poel, W. and Rzezutka, A. (2017). Hepatitis E. Global Water Pathogens Project. http://www.waterpathogens.org . (Jiménez-Cisneros, J.B.Rose and., B, ed.).

Vinjé, J (2015). Advances in laboratory methods for detection and typing of norovirus. Journal of clinical microbiology. 53, pp. 373-381.

Vuitton, D., Zhang, W. and Giraudoux, P. (2017). Echinococcus spp.. Global Water Pathogens Project. http://www.waterpathogens.org. (Jiménez-Cisneros, J.B.Rose and., B, ed.).

Ward, R.L, Bernstein, D.I, Young, E.C, Sherwood, J.R, Knowlton, D.R and Schiff, G.M (1986). Human rotavirus studies in volunteers: determination of infectious dose and serological response to infection. J Infect Dis. 154, pp. 871-80.

White, G.F., Bradley, D.J. and White, A.U. (1972). Drawers of water domestic water use in East Africa.

WHO (2014). A global brief on vector-borne diseases. Geneva, Switzerland

WHO (2003). Emerging Issues in Water and Infectious Disease. Geneva, Switzerland

Wolf, J, Prüss-Ustün, A, Cumming, O, Bartram, J, Bonjour, S, Cairncross, S et al. (2014). Systematic review: assessing the impact of drinking water and sanitation on diarrhoeal disease in low-and middle-income settings: systematic review and meta-regression. Tropical Medicine \&amp; International Health. 19, pp. 928-942.

Wybo, I, Breynaert, J, Lauwers, S, Lindenburg, F and Houf, K (2004). Isolation of Arcobacter skirrowii from a Patient with Chronic Diarrhea. Journal of Clinical Microbiology. 42, pp. 1851-1852. doi: 10.1128/JCM.42.4.1851-1852.2004.

Zaleski, KJ, Josephson, KL, Gerba, CP and Pepper, IL (2005). Potential regrowth and recolonization of salmonellae and indicators in biosolids and biosolid-amended soil. Applied and environmental microbiology. 71, pp. 3701-3708. 